Leonid Kulikov (Ghent)

\author{
Leonid Kulikov (Ghent)
}

\title{
The First Woman Yamī, Her Origin and Her Status IN INDO-IRANIAN MYTHOLOgY: DEMIgODdESS OR Half-human? (Evidence From Rggeda 10.10, Iranian Parallels and Greek Relatives)*
}

\section{Yama and Yamī in Vedic mythology: introductory remarks}

he story of Yama and Yamī is undoubtedly one of the most fascinating and
intriguing episodes of Vedic mythology. I shall first recapitulate the plot of this legend as well as its mythological and socio-cultural context.

Our main source of information about Indo-Iranian mythology is of course the Rgveda (RV) - the most ancient Vedic (Old Indo-Aryan and, more generally, Indo-Iranian) text - as well as the Atharvaveda. Both texts document the early Vedic period, which can be tentatively dated to the end of the second half of the II millennium BC. In addition, some information can be gleaned from other Vedic Saṃhitās (Yajurveda) and Vedic prose (Brāhmaṇas), as well as - to some extent - from younger, post-Vedic texts (Epics, Purānas etc.).

According to Vedic mythology, Yama and his twin sister Yamī are the first humans, who thus have a peculiar position among other mythological figures. Yama, the first mortal (mrtya) and thus the first human doomed to die, acquires a remarkable status of the king of the realm of dead after his death. Although it is clear that the pair of twins do not belong to the Vedic gods, their position within the Vedic pantheon is far from clear. Obviously, being children of some non-human (divine?) creatures, they cannot be considered as normal humans either.

Although the Indo-Iranian age of this myth is beyond any doubt - as clearly indicated by the Avestan (Yima) and Nuristāni (Im-(ra)) cognates of Yama, let alone the numerous parallels in Old and Middle Iranian tradition - the exact character of the relationship between Yama and Yamì remains one of the greatest puzzles

\footnotetext{
* I would like to take this opportunity to express my thanks to the audience of the conference "Female Deities and Demons in Indo-European Culture" (University of Łódź, 19-21 October 2017) and the $8^{\text {th }}$ Dubrovnik International Conference on the Sanskrit Epics and Purānas (Dubrovnik, 11-16 September 2017) - where parts of this paper were presented - as well as to the two anonymous reviewers for valuable comments and critical remarks.
} 
of Indo-Iranian mythology. While Yama, as the god of death and the underworld, is the addressee of a few RVic hymns, the information about his sister Yamī is much scarcer: it is essentially limited to the famous dialogue hymn RV 10, 10, which is still quite poorly understood and constitutes one of the most fascinating and yet most difficult RVic texts from the linguistic, philological and exegetic point of view ${ }^{1}$.

The central topic of this dialogue hymn is the intricate relationship between Yamī and Yama. Yamī (who authors each odd stanza, i.e. first, third, fifth etc.) attempts to seduce her twin into an incestual relationship. Yama, who replies in the even stanzas (second, fourth etc.), refuses this invitation. Yamī continues to insist, drawing further arguments, such as the necessity of producing offspring and thus continuing humankind; their prenatal physical union in the womb of their common mother; etc. Yet, Yama keeps arguing that the incestuous relationship is inappropriate and strictly prohibited, which makes their sexual encounter impossible.

\footnotetext{
${ }^{1}$ This hymn has been repeatedly translated and analysed in Vedic scholarship, remaining one of the most vividly debated texts of Vedic literature. Alongside the classic full translations of the RV, which also offer translations of and comments on RV, 10, 10 (Der Rigveda oder die heiligen hymnen der Brâhmana, vol. I-II, trans. A. Ludwig, Prag 1876 and Der Rigveda oder die heiligen hymnen der Brâhmana, vol. IV-V, Commentar zur Rigveda-übersetzung A. Ludwig, Prag-Leipzig 1883 (cetera: Ludwig); Rig-Veda, vol. II, trans. et comm. H. Grassmann, Leipzig 1876-1877, p. 296-297, 514; Der Rig-Veda, vol. III, trans. et comm. K.F. Geldner, Cambridge Massachusetts 1951 [= HOS, 33-35] (cetera: Geldner), p. 132-136; Ригведа. Мандалы IX-X, trans. et comm. Т.Я. ЕлизАРенкова, Москва 1999 (cetera: ЕлизА венкова), p. 124-126, 418-420; The Rigveda. The Earliest Religious Poetry of India, vol. III, trans. et comm. S.W. JAMISON, J.P. Brereton, New York 2014 (cetera: JAMISON and Brereton), p. 1380-1383), this hymn is included in several anthologies (Hymnes spéculatifs du Véda, trans. et comm. L. Renou, Paris 1956 (cetera: Renou), p. 55-57, 236-237; The Rig Veda. An Anthology. One Hundred and Eight Hymns, trans. et comm. W. Doniger O'Flaherty, London 1981, p. 247-250). A detailed commentary of this hymn can also be found in the monographic study of the dialogue hymns in the Rgveda, S. Schnaus, Die Dialoglieder im altindischen Rigveda. Kommentar unter besonderer Berücksichtigung textlinguistischer Kriterien, Hamburg 2008, p. 163 191. Large parts of the hymn are also translated and discussed in M. Ježıć, Rgvedski himni. Izvori indijske kulture i indoeuropsko nasljede, Zagreb 1987, p. 181sq. and J. EHni, Der Vedische Mythus des Yama verglichen mit den analogen Typen der Persischen, Griechischen und Germanischen Mythologie, Strassburg 1890. It has been the subject of several articles (U. SchneIder, Yama und Yami (RVX 10), IIJ 10, 1967, p. 1-32; H.W. Bodewitz, The Dialogue of Yama and Yami (RoV. 10, 10), IIJ 52, 2009, p. 251-285; G.-J. Pinault, Sur l'hymne védique dialogué de Yama et Yamī (RV X.10), [in:] Yamal Yima. Variations indo-iraniennes sur la geste mythique = Variations on the Indo-Iranian myth of Yama/Yima, ed. S. Azarnouche, C. Redard, Paris 2012 [= PICI. Série in 8, 81], p. 139-178, to name the most important works). For a discussion of the Indo-European roots and parallels of the myth, see, among many others, B. Lincoln, The Lord of the Dead, HR 20, 1981, p. 224-241, p. 224sqq.; В.В. Иванов, В.Н. Топоров, К проблеме лтши. јитіs и балтийского близнечного культа, БСИ 1981, p. 140-175; as well as, most recently, N. Oettinger, Before Noah: Possible Relics of the Floodmyth in Proto-Indo-Iranian and Earlier, [in:] Proceedings of the $24^{\text {th }}$ Annual UCLA Indo-European Conference, ed. S.W. Jamison, H.C. Melchert, B. Vine, Bremen 2013, p. 169-183 (this paper has unfortunately been unavailable to me).
} 
The most important characteristics and features of Yamī as a mythological personage can thus only be recovered from the text of this dialogue on the basis of its thorough linguistic, philological and text-critical study. Let us take a closer look at this text, paying special attention to the differences in the behaviour of the twins.

\section{Rgveda 10.10: a linguistic and text-critical study of the relevant stanzas}

\subsection{Rgveda 10.10.1: Yamī invites Yama to a sexual relation}

The first half (pādas ab) of the first stanza of the hymn runs as follows (for clarity, I provide morphological glossing):

\begin{tabular}{|c|c|c|c|c|}
\hline $\begin{aligned} \text { (1) } o^{[}[=\bar{a}=u] \\
\text { to }=\text { PTCL }\end{aligned}$ & $\begin{array}{l}\text { cit } \\
\text { PTCL }\end{array}$ & $\begin{array}{l}\text { sákhāyam } \\
\text { friend:ACC.sG }\end{array}$ & $\begin{array}{l}\boldsymbol{s a k h}_{\boldsymbol{i}} \boldsymbol{y} \dot{\bar{a}} \\
\text { friendship:??? }\end{array}$ & $\begin{array}{l}\text { vavrtyām } \\
\text { turn:PF:1sG.ACT }\end{array}$ \\
\hline tiráh & purín & cid & arṇavám & jagan-vấn \\
\hline through & many:??? & PTCL & flood:ACC.sG & go:PF-PTC.ACT:NOM.SG.M \\
\hline
\end{tabular}

Linguistically, the most difficult form of this passage and one of the most debated forms of the whole hymn is sakhyá in the first line of the hymn (pāda a). This is the abstract noun derived from sákhi- 'friend, partner, companion' (the accusative singular form of which, sákhāyam, immediately precedes sakhyáa), thus meaning 'friendship, partnership', but its exact grammatical characteristics remain unclear. Another difficult word that may require special comments is purú in pāda b. In their recent English translation of the Rogveda Stephanie W. Jamison and Joel P. Brereton render these two verses as

I would turn my partner right here to partnership - even though he has gone across many (realms), across the flood [emphasis is mine - L.K.] ${ }^{2}$.

Translating sakhyá as 'to partnership', they obviously follow the standard German translation and interpretation by Karl Friedrich Geldner:

Ich möchte doch den Freund zu einem Freundschaftsdienst bewegen.

Auch wenn er noch so viele (Meilen), über das Meer gegangen ist, (sollte er kommen) ${ }^{3}$.

Geldner explains his interpretation in a note drawing upon a conjecture: he saw in sakhyá a truncated form of the dative singular form (sakhyá Dat. für sakhyấya), thus ultimately following Sāyaṇa's indigenous commentary and subscribing to the

\footnotetext{
${ }^{2}$ JAMISON and BRERETON, vol. III, p. 1382.

${ }^{3}$ Geldner, vol. III, p. 412.
} 
analysis put forth by Richard Pischel ${ }^{4}$. However, this analysis - adopted by many Sanskritists ${ }^{5}$ - appears questionable: as Hermann Oldenberg ${ }^{6}$ convincingly argues, the heavy emendation $\left({ }^{+}\right.$sakhyá $\left.[y a]\right)$ is unnecessary.

In fact, sakhyá can be satisfactorily analysed as a grammatically correct form of the abstract substantive sakhyá- 'friendship, partnership' without any emendation. One such formal option is to take sakhy $\bar{a}$ as the instrumental singular form ${ }^{7}$, adopted, for instance, by Susanne Schnaus', who sees here an "Instrumental des Grundes" and translates this passage as follows:

Herbei möchte ich den Freund aufgrund der Freundschaft wenden.

Er ist über wirklich vieles hinweg zum wallenden Meer gegangen.

Albeit formally possible, this analysis does not make much sense: the instrumental of cause (I would like to invite a friend because of friendship?) appears redundant in this context.

The other available option ${ }^{9}$ is to take sakhyá as an accusative plural form, thus rendering pāda a as I would like turn my friend towards friendships... or the like, which makes the dative analysis (sakhyá $[y a])$ unnecessary. As Oldenberg ${ }^{10}$ rightly noticed, the accusative of goal is quite common with the verb $\stackrel{a}{a}-v r t$. This analysis was adopted, in particular, by Louis Renou ${ }^{11}$ as well as, most recently, by Hendrik Wilhelm Bodewitz ${ }^{12}$ and Georges-Jean Pinault ${ }^{13}$. The last two authors disagree as regards the exact rendering of the verbal form: Bodewit $\mathrm{z}^{14}$ believes that it can be interpreted as '(make) return to' ([a]pparently Yamī wants to get back the

\footnotetext{
${ }^{4}$ R. Pischel, Vedische Studien, vol. I, Stuttgart 1889, p. 64sqq.

${ }^{5}$ Renou, p. 55: Que ne puis-je vers l'amitié attirer mon ami, fût-il allé au loin, par delà les mers! Later, L. Renou (Études védiques et pāninéennes, vol. XVI, Paris 1967, p. 122) abandoned his earlier analysis, subscribing to the view of H. Oldenberg (Rgveda. Textkritische und exegetische Noten, vol. II, Siebentes bis zehntes Buch, Berlin 1912) instead, see below. U. SchNeIDER, Yama und Yamī..., p. 3: Herbei, unter allen Umständen, [ó cit] möchte ich den Genossen zur gemeinsamen Sache bewegen. Auch wenn er noch so weit über das Meer [arnavá] gegangen ist... DONIGER O'FlaherTy (The Rig Veda. An Anthology..., p. 247): Would that I might draw my friend into intimate friendship, now that he has gone far across the ocean. JAMISON and BRERETON, quoted above.

${ }^{6}$ H. Oldenberg, Vedische Untersuchungen, ZDMG 63, 1909, p. 287.

${ }^{7}$ C.R. Lanman, A Statistical Account of Noun-inflection in the Veda, JAOS 10, 1880, p. 336; LudwIG, vol. V, p. 511.

${ }^{8}$ S. Schnaus, Die Dialoglieder..., p. 163sq.

${ }^{9}$ Put forth by H. Oldenberg, Vedische..., p. 287; Idem, Rgveda. Textkritische..., ad loc., p. 204.

${ }^{10}$ IDEM, Vedische..., p. 287.

${ }^{11}$ In his posthumously published comments on RV, 10, 10; see L. Renou, Études védiques..., p. 122, and this analysis is also adopted in Елизаренкова, p. 419; however, her translation - Как бы я хотела повернуть друга к дружбе... (ibidem, p. 124) - rather suggests the dative analysis of the form.

${ }^{12}$ H.W. Bodewitz, The Dialogue..., p. 256sq.

${ }^{13}$ G.-J. Pinault, Sur l'hymne..., p. 144sq.

${ }^{14}$ H.W. Bodewitz, The Dialogue..., p. 257.
} 
situations of friendship (therefore the plural is used), but now with a special form of sexual partnership), while Pinault doubts this interpretation (Yami ne propose pas à Yama de "revenir" à une "amitié" antérieure: aucun terme n'implique l'idée de retour. Le pluriel de labstrait sakh(i)yá- ajoute à la tonalité officielle et délibérément euphémistique de l'intervention de Yamī $)^{15}$. Pinault's objection against Bodewitz's translation of the verb $\bar{a}$ - $v r t$ appears fully justified, but his own explanation of the meaning of the plural form does not seem convincing either: the exact meaning of sakhyá remains unclear. Let us take a closer look at the semantics of this plural noun, paying special attention to the possible semantic nuances induced by the pragmatic context of Yamîs response addressed to Yama.

First of all, it should be borne in mind that Yamī encourages her brother to become her sexual partner. Therefore, the meaning of the accusative sákhāyam should be rendered not just as 'friend' or 'partner', but, rather - more precisely - as 'sexual partner. Thus, Yamī is anticipating the future type of relationship with Yama which she is eager to achieve, rather than referring to the actually existing type of relation. Accordingly, the abstract noun sakhyá-, derived from a noun with this particular meaning, should be understood as 'sexual partnership, sexual relation' (which, in fact, is very close to Bodewitz's proposal quoted above). How can a plural form of such a noun be interpreted? As is well-known, abstract nouns are typically uncountable, thus very often being unable to form plural forms (singularia tantum). When a noun of this class nevertheless does form a plural, this necessarily implies a semantic shift ${ }^{16}$. Specifically, the plural form of a noun denoting an abstract notion $\mathrm{Q}$ may either refer to various sorts of Q (e.g. friendships = various types of friendship) or multiple realizations of $Q$ (e.g. beauties $=$ many realizations or occurrences of beauty). The former option makes little, if any, sense in our case: I would like to turn my partner to [various sorts of] friendship/(sexual) partnership? By contrast, the latter, in my view, perfectly fits into the context of Yamî's offer: I would like to turn [= invite] my sexual partner to [many realizations of] sexual partnership. In other words, Yamī encourages Yama to perform many acts of love with her ${ }^{17}$. Furthermore, this interpretation is indirectly supported by the form purú 'many' in the next pāda b, which is usually taken as lacking an overtly expressed syntactic head ${ }^{18}$ and thus syntactically hanging. Instead of restoring the ellipsis of a hypothetical head of purú within pāda b, one might tentatively connect it with sakhy $\bar{a}$. Although they are separated by as many as two words, it does not seem syntactically impossible, if purú is regarded as Yamī’s delayed (and thus somewhat

\footnotetext{
${ }^{15}$ G.-J. Pinault, Sur l'hymne..., p. 144.

${ }^{16}$ As noticed in many linguistic handbooks; see, e.g. O. Jespersen, A Modern English Grammar on Historical Principles, pars 2, Syntax, vol. I, London-Copenhagen 1949, p. 114sqq.

${ }^{17}$ Quite close to this interpretation is BoDEwitz's 'situations of friendship'.

${ }^{18}$ Cf. JAmison and Brereton: 'many (realms)', vol. III, p. 1382; Geldner: 'so viele (Meilen)', vol. III, p. 412.
} 
camouflaged) addition to her sexual offer: I would like to turn my sexual partner to make love with me, many [times], lit..... to loves,... many [loves]!

To sum up, in the very first line of the hymn, Yamin invites Yama - as his potential partner - to repeatedly have sex with her, thus exhibiting sexually explicit behaviour. This hypersexuality of Yamī is in striking contrast to the wholly different and most reserved conduct of her brother, who is constantly trying to calm Yamī down. We find further evidence for this drastic difference in another verse of the same hymn, this time in Yama's response.

\subsection{Rgveda 10.10.6d: Yama blames Yamī for her sexually explicit behaviour}

In stanza 6, after pointing to the supreme character of Mitra and Varuna's laws (10.10.6c: brhán mitrásya várunasya dhấma), in the last pāda (d), Yama blames his sister for her indecent behaviour:

\begin{tabular}{|c|c|c|c|}
\hline kád u & brava & ähano & $v \overline{\bar{c}} \boldsymbol{c}_{i} y \bar{a}$ \\
\hline
\end{tabular}

How can you talk, [ vícyā $]$, o lustful (one) (?), to men!?

This is the most difficult line in the stanza and, again, one of the most difficult passages in the entire hymn. The two problematic forms here (shown in boldface) are the rare word āhanás- (in the vocative form) and the hapax vícyā. Although it is evident that Yama accuses Yamī of her sexually explicit behaviour, the exact meaning of these two forms, which constitute the main content of this accusation, is unclear.

āhanás- is usually translated as 'lustful, obscene', but its etymology remains a subject of debate. Elsewhere ${ }^{19} \mathrm{I}$ argued that Manfred Mayrhofer's ${ }^{20}$ translation of this form as 'schwellend, strotzend, geil, üppig' and its derivation from the hypothetical root " $g^{h} e n$ - 'schwellen' should be rejected. Here, I will briefly summarize the main conclusions of that paper. As I argue, the analysis of this form as an -as-derivative of the root han 'hit, beat, strike' (with the preverb $\bar{a}$ ), adopted by Christianus C. Uhlenbeck ${ }^{21}$, who obviously followed Otto von Böhtlingk and Rudolf von Roth's Sanskrit-Wörterbuch ${ }^{22}$ - should ultimately be accepted, though

\footnotetext{
${ }^{19}$ L. Kulikov, Vedic āhanás- and Its Relatives / Cognates within and outside Indo-Iranian, [in:] Farnah. Indo-Iranian and Indo-European Studies in Honor of Sasha Lubotsky, Ann Arbor 2018, p. 153-161.

${ }^{20}$ M. MaYrhofer, Etymologisches Wörterbuch des Altindoarischen (cetera: EWAia), vol. I, Heidelberg 1986, p. 184.

${ }^{21}$ C.C. Uhlenbeck, Kurzgefasstes etymologisches Wörterbuch der altindischen Sprache, Amsterdam 1898/1899, p. 23.

${ }^{22}$ O. BöнtLINGK, R. Roth, Sanskrit-Wörterbuch, vol. I, St. Petersburg 1855, p. 746: schwellend, strotzend, üppig, āhanás-, zu hánti schlägt (vgl. russ. nabítyj voll zu bítǐ schlagen und ghanás);
} 
assuming a semantic development different from that envisaged by Böhtlingk. In fact, the connection between the primary meaning of the root han, 'beat, strike' and the meaning 'make love, have sex, fuck' is obvious and hardly requires special argumentation. This semantic development, in accordance with the diachronic scenario 'beat, strike' $\rightarrow$ 'perform sexual strikes' $\rightarrow$ 'perform sexual movements', is universal and occurs in many languages ${ }^{23}$. Under this analysis, āhanás- clearly represents a derivative in -as-based on the compounded verb $\dot{a}$-han. This compound is relatively rare in Vedic, yet we find the following remarkable example of a -taadjective derived from this compound in the wedding hymn RV 10, 85:

śúcī te cakré yāt yóa ' vyānó ákṣa áhata ${ }^{24}$

The two gleaming ones [= Heaven and Earth?] were your two wheels as you drove. Breath was hammered in as the axle ${ }^{25}$.

Obviously, at least one of the meanings of the compound $\dot{a}$-han was 'hammer in, insert, stick (in)', said in particular of an axle inserted into the hub of a wheel. Given the common connection between the meanings 'beat' and 'perform sex', the compound $\dot{a}$-han could easily develop the sexual meaning 'insert, hammer in' (of a penis). The sexual metaphors of the type 'insert the axle into the hub of a wheel' 'insert the penis into the vagina' or 'two rolling wheels (connected with an axle)' $\sim$ 'two lovers having sex' (note that this erotic connotation is particularly appropriate in the context of the wedding hymn RV 10,85) is of course obvious and does not require special comments. The meaning 'lascivious, lustful, obscene' can be obtained for the agentive masculine -as-derivative of this compound, āhanás-, as developing from 'the one who strikes in(side), the one who hammers in'.

While the lexeme āhanás- is at least etymologically clear and can be unambiguously identified as an -as-derivative of the compound $\dot{\bar{a}}$-han, vícy $\bar{a}$ is obscure even at the morphological level. Some scholars have taken it as an absolutive (converb) of a compound verb with the preverb $v i^{2}{ }^{26}$, but such an analysis is untenable: there

more accurate would be comparison with Russ. взбumbiŭ 'whipped' (of cream). The meaning 'lustful' was obviously understood by Böhtlingk as based on 'overstuffed, swollen' [vollgestopft, überfüllt] $\rightarrow$ 'curvaceous, voluptuous, buxom', discarded in M. MAYrHOFER, Kurzgefaßtes etymologisches Wörterbuch des Altindischen = A Concise Etymological Sanskrit Dictionary, vol. I, Heidelberg 1956, p. 84.

${ }^{23}$ Cf. Eng. fuck PIE *peu'( $\hat{g}^{-}$- 'prick, stab'; Latin futuo 'fuck, copulate' -futo 'strike'; Rus. (vulg.) трахнуть ('beat' $\rightarrow$ ) 'screw, fuck', etc.

${ }^{24} \mathrm{RV}, 10,85,12 \mathrm{ab}$.

${ }^{25}$ JAMISON and BRERETON, vol. III, p. 1522.

${ }^{26}$ E.g. vi-yāc 'ask' in S. Schnaus, Die Dialoglieder..., p. 174sqq. In her translation: Wirst du sprechen, Geile, die Männer bitten? This analysis is impossible for several reasons: first, as Schnaus herself notices, this compound does not occur in Vedic; second, and most importantly, the zero grade $\bar{\imath} c$ - is never attested for this non-alternating root, which always appears in the full grade $y \bar{a} c-$. 
is no root which could yield the zero grade -ic- in the absolutive. More plausible is the analysis ${ }^{27}$ as the instrumental singular feminine form derived from the hypothetical adjective $v y$-áñc-, with the suffix -añc- of the type $u d$-áñc- 'directed upwards', prá̃ $\tilde{n} c$ - 'directed forwards' etc. Most such adjectives are based on spatial preverbs: úd- 'up', prá- 'forwards' etc. This analysis is readily adopted by most Vedicists, but, again, the exact meaning of the form is not yet correctly understood in my view. The syntactically 'hanging' adjective suggests the ellipsis of a feminine head noun. The missing substantive is restored by most scholars as vắc'speech', and the form in question is rendered as 'with diverted, deviant [speech]' or the like ${ }^{28}$. This analysis seems dubious. First of all, vấc- does not normally occur in constructions with spatial adjectives. The basic meaning of the preverb $v i$ - (etymologically relying on " $d v i s$ - 'in two ${ }^{29}$ ) is 'apart, asunder, in two', rather than 'aside, deviating. Accordingly, the meaning of $v y$-áñc-should be determined - in accordance with the basic (and etymological) meaning of $v i$ - - as 'directed apart, spread (out)'. This meaning makes little sense in the context of $v \bar{a} c$ - 'speech' (which, incidentally, does not occur in the text of RV 10,10). However, it is perfectly plausible in a construction with another feminine substantive, which, unlike v vấc-, occurs as many as six times in RV 10, 10: $\tan \bar{u}$ - 'body'. Supplying the instrumental $\tan v \overline{\bar{a}}$, we obtain the meaning '[with the body/legs] spread out', which, most probably, refers to some sort of an obscene posture. The latter can, incidentally, be readily illustrated with Classical Indian sculpture (see Fig. 1a) as well as with several iconographic images that have developed in some branches of Hinduism (where this particular 'spreading' posture could have acquired special importance; see Fig. $1 \mathrm{~b}$ representing the Tantric goddess of desire Kamakhya, worshipped in Assam $)^{30}$. The entire pāda d can now be tentatively translated as: How can you talk to men, taking an obscene posture [= with legs spread out ${ }^{31}$ ], o eager one to have sex!?

\footnotetext{
${ }^{27}$ Proposed already by H. Oldenberg, Rgveda. Textkritische..., ad loc. and adopted, for instance, by RENOU and GeLDNER.

${ }^{28}$ Thus H. Oldenberg (Rgveda. Textkritische..., ad loc.): mit sich entfernender (von Wahrheit, Sittlichkeit abweichender) (Rede), with question mark; RENou, p. 56: 'avec cette malice'; G.-J. PINAULT, Sur l'hymne..., p. 153sqq.: Lascive, parleras-tu aux hommes d' une façon qui la contrarie; JAMIson and BRERETON, vol. III, p. 1382): 'with deviant (speech)'.

${ }^{29}$ See A. Lubotsкy, $R V$. ávidhat, [in:] Früh-, Mittel-, Spätindogermanisch. Akten der IX. Fachtagung der Indogermanischen Gesellschaft vom 5. bis 9. Oktober 1992 in Zürich, ed. G. DunKeL et al., Wiesbaden 1994, p. 201-206.

${ }^{30}$ Even though such images come from a much later time, their very presence in the Indian iconographic tradition and religious art may point to the archaic character of the corresponding conceptual pattern.

${ }^{31}$ Among the existing translations, the one closest to the present proposal is probably ЕлизАРенковА, p. 125: О сладострастная, что же ты обращаешься с (таким) соблазном к мужчинам?
} 


\subsection{Rggeda 10.10.7cd: Yamī's sexual metaphors}

Yet another passage which betrays Yamîs hypersexuality is found in the next stanza, where Yamī once again invites Yama to have sex with her. In the last two verses of the stanza, we read:

jāyéva pátye $\tan _{u}$ vàm riricyām ' ví cid vrọheva ráth $\mathrm{i}$ yeva cakrấ

While the translation of pāda c does not pose any difficulties (Like a wife to the husband I would like to offer [him] [my] body), the exact meaning of the optative verbal form ví... vrheva in pāda d Let us... [?] like two wheels of a chariot! is difficult to determine on the basis of the constituents of the compound ví-vrh, i.e. $v i$ - 'apart' $+v r h$ 'tear (out)'. Still, given that the image of the two wheels is commonly used in Vedic as a sexual metaphor (as in RV 10, 85, 12 quoted above), the verbal form in question should probably be understood as referring to intensive sex, compared to the movements of the two wheels of a chariot connected with an axle and alternating two opposite types of movements: insertion and tearing out ( $v i$ - vrh $)$. Accordingly, the last pāda can be tentatively translated as follows: Let us roll, mutually screwing [in and] out like two wheels of a chariot!

To sum up, Yamī demonstrates remarkable sexually explicit behaviour, which is in drastic contrast with that of her brother. This may be the key to a better understanding of their mythological status as well as their role in the continuation of the human race. In order to clarify this issue, we have to take a closer look at the ancestry of the first humans.

\section{Two versions of Yama and Yamī's ancestry}

According to the standard genealogy of Yama and Yamī, they are the children of the solar god Vivasvant (one of the manifestations of Sūrya; see Fig. 2) and his consort Saranyū, the daughter of Tvașțar (note that in stanza 5 Yamī appeals to her grandfather as a witness of their common origin from the same womb) ${ }^{32}$.

Yet, once in our hymn, in RV 10, 10, 4, we come across a different - and less exalted - version of Yama and Yamîs ancestry. It is summarized by Yama as follows:

gandharvó aps v vápyā ca yóșā ' sáa no ná bhih... ${ }^{33}$

A gandharva in the waters, and a young woman connected with water - that is our origin...

[i.e. blood relationship].

${ }^{32} \mathrm{Cf}$., for instance, RV, 10, 14, 10, 135, 10.154; in RV, 10, 14, 1 we find an explicit mention of vaivasvatám... yamám rấjānam (Yama the king, the son of Vivasvant).

${ }^{33} \mathrm{RV}, 10,10,4 \mathrm{~cd}$. 
The expression ápyā... yóșa 'woman connected with water' undoubtedly refers to an Apsara. Thus, we find here an entirely different version of the origin of Yama and Yamī. Although several attempts have been made to reconcile this controversy by identifying Vivasvant with Gandharva - thus taking the two as mere alternant names of the same god ${ }^{34}$ - they do not appear convincing. Rather, one should take this brief reference more seriously, as it may provide the key to the explanation of Yamī and Yama's behaviour and, more generally, of their status in the mythological pantheon.

\section{Gandharva in the early Vedic pantheon and Indo-Iranian mythology}

In classical Hindu mythology, the Gandharvas and the Apsaras have a rather modest status of semi-divine creatures, acting as celestial musicians and dancers, respectively. The Apsaras are often represented as beautiful seductive women, and this image can be traced back as far as the early Vedic period. However, their characteristics in the early Vedic period - as documented in the earliest Vedic texts, such as above all the Rgveda and the Atharvaveda - are quite different from what we find about these rather harmless figures in later Hinduism. In the early Vedic divine hierarchy, the Gandharvas (with their spouses, the Apsaras) occupy a rather low rank of semi-divine or demonic creatures, yet of a fairly dangerous nature. They are mentioned in the Rgveda relatively rarely (ca. 20 times) ${ }^{35}$, and their status remains obscure in several respects.

Thus, in the wedding hymn RV 10, 85 we read that the Gandharva is granted special access to the bride, after Soma ${ }^{36}$. This technique, not infrequent in many mythologies and magic rituals, is presumably aimed at pacifying dangerous creatures:

sómah prathamó vivide ' gandharvó vivida úttarah ${ }^{37}$

Soma has known [the bride/wife] first; Gandharva has known [her] the second...

More information about the features of and especially the dangers caused by the Gandharvas and the Apsaras can be gleaned from the Atharvavedic spell

\footnotetext{
${ }^{34}$ E.g. J. Ehni, Der Vedische..., p. 142sq.; L.D. BARnett, Yama, Gandharva, and Glaucus, BSOS 4, 1928, p. 703-716.

${ }^{35}$ All relevant passages are collected and discussed by C. HaAs (Wie man den Veda lesen kann. Gandharva und die "Zwischenzustände" im Rgveda und im Kommentar des Säyaṇa. Wege der Interpretation eines archaischen Textes, Göttingen 2004 [= HSf, 43]), although her conclusions are rather debatable; see S.W. JAMISON, [rec.:] C. Haas, Wie man den Veda lesen kann... - JAOS 128, 2008, p. 394-395. For an overview, see for instance A.A. MACDonell, Vedic mythology, Strassburg 1897, p. 134-138; U.G. Thite, Gandharvas and Apsarasas in the Veda, JIMS 18, 1987, p. 52sqq.

${ }^{36}$ For a discussion of this attitude, see e.g. C. HaAs, Wie man..., p. 140sqq.

${ }^{37} \mathrm{RV}, 10,85,40$.
} 
"Against Gandharvas and Apsaras with Arāțakī-plant". In what follows, I quote a few relevant fragments of this spell, attested in both recensions, Śaunakiya (cetera: AVŚ) and Paippalāda (cetera: AVP) ${ }^{38}$, AVŚ $4.37 \approx$ AVP 12.7-8.

The magic Arātakî-plant is intended to expel Apsaras and Gandharvas with its fragrance (gandhá-), as we read in stanza 2 of this hymn:

tváyā vayám apsaráso ' gandharvấṃ́s cātayāmahe I

ájaśringy ája rákșah ' sárvān gandhéna nāśaya ${ }^{39}$

We chase away with you Apsaras und Gandharvas. O goat-horned [herb], drive away the Rakșas, make them all disappear with [your] fragrance.

Particularly valuable information about the features and aspects of the Gandharvas is found in the second half of the spell. In the stanza AVP 12, 8, $4 \approx$ AVS $4,37,10$, Gandharva is described as a scary demonic creature living in marshy landscapes:

avakādān 'abhiśocān ' bhitsu [Śaun. apsú] dyotayamāmakān I

gandharvān sarvān oṣadhe ' pra ṇudasva parā nạa $a^{40}$

O plant, push away, carry away the gandharvas, the avaka-eaters ${ }^{41}$, [who appear as] shining will-o'-the-wisps in the splits (Paipp.) / in the waters (Śaun.).

The ability to take different forms and shapes accounts for the dangers that this creature poses to young women:

śvévaikah kapír ivaikah ' kumāráh sarvakeśakáh I

priyó drśá iva bhütvā' gandharváh sacate stríyas ${ }^{42}$

One [appears] as a dog, another as an ape, yet another, becoming like a young man having all [kinds of] hair [= including pubic hair = sexually adult], pleasant for seeing, a gandharva runs after women.

\footnotetext{
${ }^{38}$ Atharva-Veda Samhitā, trans. et comm. W.D. Whitney, ed. C.R. Lanman, vol. I, Cambridge Massachusetts 1905 [= HOS, 7], p. 211-213; Atharvaveda (Šaunaka), trans. et comm. T.Ja. EliARENKova, vol. I, Moskva 2005, p. 210-211, 449-450. Alongside the existing translations of the Saunakiya recension, I use the unpublished edition and translation of the Paippalāda book 12 by G. Ehlers.

${ }^{39}$ AVŚ, $4,37,2 \approx$ AVP, $12,8,4$.

${ }^{40} \mathrm{AVP}, 12,8,4 \approx \mathrm{AVŚ}, 4,37,10$.

${ }^{41}$ Avaka- - a grassy herb (Blyxa Octandra Rich.) growing on marshes, partly under water.

${ }^{42}$ AVŚ, 4, 37, 11abcd $\approx$ AVP, 12, 8, 6cdef.
} 
The lustful character of this creature explains why, instead of killing it, it suffices to neutralize a Gandharva sexually, making him impotent:

\author{
ānŕtyatah śikhandíno ' gandharvásyāpsarāpatéh I

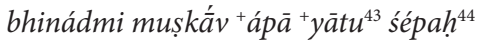

Of the hither-dancing, crested gandharva, Apsaras-lord, I crush [his] testicles, let [his] penis become unerect [= let this gandharva become impotent]!

The evidence available from this Atharvavedic spell clearly shows that the Apsaras and especially the Gandharvas are not (yet) as harmless as in the classical period. The latter creatures, lustful and sexually aggressive, are particularly dangerous for young women. I cannot help noticing that, in this respect, Yamī is a worthy heir of her semi-divine or demonic parents, viz. her seductive mother and particularly her lustful father. In this perspective, many peculiarities of her sexually explicit or even indecent conduct, of which her brother accuses her (himself exhibiting a most distinct, constrained type of behaviour) in RV 10, 10, 6, can be satisfactorily accounted for.

There is yet another Sanskrit form that may be relevant for the discussion of the origins of the form gandharvá-, namely the name of the love god kandarpa(see Fig. 3). Although this name is not found in Vedic texts, first occurring from the Epics onwards, its remarkable similarity with gandharvá- ${ }^{45}$ is at least worth mentioning here. L.D. Barnett ${ }^{46}$ saw in this form the Middle Indic (Paiśācî?) reflex of gandharvá- (through $\left.{ }^{*} k a n d a p p a-?\right)$, with subsequent hypersanskritization. In modern scholarship, kandarpa- is usually regarded as non-etymologizable ${ }^{47}$, though some parts of this form may point to secondary re-etymologization, cf. kān- ( $\leftarrow$ káma- 'love') and darpa- 'madness' (?) ( $\leftarrow$ root drp- 'be mad'). Notice that the first component of such hypothetical compound would rather be expected in the form kāma-, while darpa- typically means 'pride, arrogance, haughtiness', not 'madness (caused by love)' or the like.

The isolated character of the genealogical statement about Yama and Yamiss origin from a Gandharva and an Apsara might produce the impression that this ancestry of the twins is uncertain and should not be taken seriously, in favour

\footnotetext{
${ }^{43}$ My own conjecture for Śaun. ápi yāmi, Paipp. api yātu; see L. Kulıkov, The Vedic-ya-presents. Passives and Intransitivity in Old Indo-Aryan, Amsterdam 2012 [= LSIE, 19], p. 670sq. for a discussion of this difficult verse.

${ }^{44}$ AVŚ, 4, 37, $7 \approx$ AVP, 12, 7, 9.

${ }^{45}$ Only rarely noticed in Sanskrit scholarship; see e.g. A.K. Coomaraswamy, Yakșas, pars 1-2, Washington 1928-1931; W. Norman Brown, [rec.:] A.K. CoOMARaswamy, Yakṣas, pars 1-2, Washington 1928-1931, JAOS 51, 1931, p. 288.

${ }^{46}$ L.D. BARNETT, Yama..., p. 704, an. 2.

${ }^{47}$ M. Mayrhofer, EWAia, vol. III, p. 55.
} 
of mere identification of Gandharva with Vivasvant, mentioned above. Nevertheless, in Iranian mythology we find a striking parallel which strongly supports this connection. Even though the Old Iranian cognate of Yama - Yima - is said to be a son of Vivahvan (= Vivasvant), the equivalent of Gandharva is not unknown to the Iranians either. The Avestan form gandaraba- (var. gandərəßa- and gandaraßa-; corresponding to Middle Persian Gandarw/Gandarb), the undoubted cognate of Gandharva, is the name of an aquatic monster that lived in the lake Vourukaš̉a and was killed by the hero Kərəsāspa (Mid. Pers. Kirsāsp; Mod. Pers. Karšāsp ${ }^{48}$. Most interestingly, according to Middle Iranian sources, Gaṇdarəba is born from a sexual union of Jam (= Yama) with a witch (parig; cf. Mod. Persian peri). The importance of Gandharva ( ${ }^{*}$ GandharBa?) in the Proto-Iranian mythological system is further supported by Uralic borrowings from Iranian, which include terms for dangerous animals and mythological beings (cf. Udmurt gondir 'bear', Komi-Zyrian gundir 'dragon, serpent, Hydra, evil spirit', etc) ${ }^{49}$.

The connection between Yima and Gandarəba in Iranian, though of a precisely opposite character (father - son) with regard to that between Yama and Gandharva (son - father), clearly testifies to the Common Indo-Iranian age of the blood relationship of these two figures, to which Yamī should of course be added. We thus have good reasons to reconstruct this connection for Proto-Indo-Iranian mythology.

\section{Gandharva and his cognates outside Indo-Iranian?}

While Yama and Yamī do not pose any problem from the etymological point of view, being mere terms for twins (cf. such cognates as Latv. jumis ${ }^{50}$ and perhaps - with a secondary development of the final consonant - Lat. geminus $^{51}$ ), the form gandharvá- has no good Indo-European etymology and is thus unanimously considered as non-Indo-European. Yet this does not necessarily imply the isolated character of the Gandharvas in the context of Indo-European mythology.

Already in the middle of the $19^{\text {th }}$ century, $\mathrm{Kuhn}^{52}$ attempted to connect

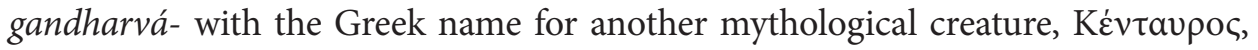
Centaur $^{53}$. For purely phonetic reasons, these two forms cannot be direct cognates in terms of regular phonetic correspondences: Gr. $\kappa$ - cannot correspond to Ved. $g$-, Gr. $\tau$ - cannot correspond to Ved. $d h$-, etc. The few existing attempts to construct

\footnotetext{
${ }^{48}$ Yašt 5, 38 (Avesta. Die heiligen Bücher der Parsen, übersetzt auf der Grundlage von Chr. Bartholomae's altiranischem Wörterbuch, 5, 38, trans. F. WolfF, Strasbourg 1910, p. 171).

${ }^{49}$ Seе В.В. НАПольских, Кентавр гандхарва дракон медведь: к эволюиии одного мифологического образа в Северной Евразии, NJAOS 5, 2008, p. 43-63.

${ }^{50}$ В.В. Иванов, В.Н. ТоПоРОВ, К проблеме..., р. 163 and passim.

${ }^{51}$ See M. Mayrhofer, EWAia, vol. II, p. 400.

${ }^{52}$ A. Kunn, Gandharven und Kentauren, ZVS 1.6, 1852, p. 513-542.

${ }^{53}$ See also E.H. Meyer, Indogermanische Mythen, vol. I, Gandharven-Kentauren, Berlin 1883.
} 
a plausible Indo-European mythology for these form ${ }^{54}$ have been unsuccessful, and this comparison is now rejected by all etymological dictionaries. Accordingly, no Proto-Indo-European source of the Vedic and Greek forms can be reconstructed: both are considered as words without an Indo-European etymology $y^{55}$.

That being said, it would be incorrect to consider the Indo-Iranian and Greek forms unrelated, given their striking similarity. Most likely, both forms go back to the same source, being borrowings from an unknown non-Indo-European language (perhaps through an intermediary).

As far as Common Indo-Iranian is concerned, it is worth mentioning that the form gandharvá- is listed among Common Indo-Iranian forms that have no (reliable) Indo-European etymology and, according to the very plausible assumption by Alexander Lubotsky ${ }^{56}$, could have been borrowed from the unidentified language spoken by the population of the Bactria-Margiana Archaeological Complex (BMAC). Dated to the last centuries of the III - first centuries of the II millennium $\mathrm{BC}$, the culture was located immediately to the south of the Andronovo culture (see Fig. 4), with which the Proto-Indo-Iranians are commonly identified.

Other words of non-Indo-European origin, presumably traceable to the same source, include, in particular, yet another religious/mythological term: átharvan-, Av. äArauuan- < PIIr. *átharuan- '(a particular type of) priest' (?) ${ }^{57}$, perhaps with the same suffixal part (-arua-).

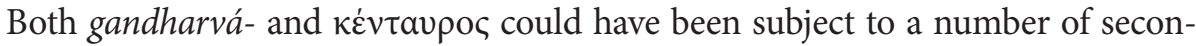
dary developments based on re-etymologization. Thus, Greek could have introduced $t$ under the influence of the word for yet another ungulate, $\tau \alpha \tilde{v} \rho o c^{\prime}$ 'bull', while the initial part, $\kappa \dot{\varepsilon} v$-, is sometimes compared with $\kappa \varepsilon v \tau \varepsilon \dot{\varepsilon} \omega$ 'pierce'. Similarly, the initial part of gandharvá- could have been modified under the influence of gandhá- 'fragrance' (likewise of unclear origin) ${ }^{58}$. Of course, this makes the re-

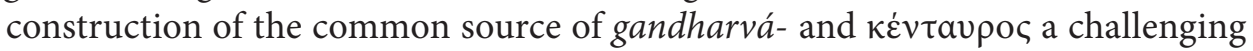

${ }^{54}$ Such as G. Dumézil, Le Problème des centaures. Étude de mythologie comparée indo-européenne, Paris 1929.

${ }^{55}$ See e.g. M. MAYrhofer, EWAia, vol. I, p. 462 and H. Frisk, Griechisches etymologisches Wörterbuch, Heidelberg 1960, p. 819sq.; P. Chantraine et al., Dictionnaire étymologique de la langue grecque. Histoire des mots, Paris 1968, p. 514sq. for Vedic and Greek, respectively. For the possible etymological connections of кévtaupos, see also P. Kretschmer, Mythische Namen. 9. Die Kentauren, Glo 10, 1920, p. 50sqq.; W. BELARDI, Consonanze mediterranee e asiatiche con il nome dei Centauri, SMSR 20, 1996, p. 23-53; A. De Angelis, Tra dati linguistici e fonti letterarie: per un'etimologia del gr.

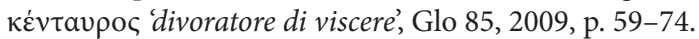

${ }^{56}$ A. Luвотsку, The Indo-Iranian Substratum, [in:] Early Contacts between Uralic and Indo-European. Linguistic and Archaeological Considerations, ed. C. Carpelan, A. Parpola, P. Koskikallio, Helsinki 2001 [= MSFO, 242], p. 301-317.

${ }^{57}$ See G.-J. Pinault, Further Links between the Indo-Iranian Substratum and the BMAC Language, [in:] Themes and Tasks in Old and Middle Indo-Aryan linguistics, ed. B. Tikkanen, H. Hetrrich, Delhi 2006, p. 167-196.

${ }^{58} \mathrm{Cf}$. the association between gandharvá- and gandhá- mentioned in AVŚ, 4, 37, $2 \approx \mathrm{AVP}, 12,8,4$. 
task. However, relying above all on the non-etymologizable parts of the two forms, one might tentatively reconstruct the source form as ${ }^{*} G e n D V r u V$ - or the like, where $G$ and $D$ stand for (voiced?) velar and dental consonants, while $V$ represents any (?) full vowel $(e, a$, or $o$ ).

\section{Gandharvas and Centaurs: mythological parallelisms}

Even though the two figures do not appear identical, the several striking parallels between them that can be observed in Indo-Iranian and Greek mythologies point to the fact that the similarity of the two forms cannot be accidental and must be due to some deeper affinity.

\subsection{Hypersexuality and water}

Both Gandharvas and Centaurs are notorious for their lustful character and sexually aggressive behaviour ${ }^{59}$. The post-Vedic name of the love god Kandarpa, which might be another variant of the form gandharvá-, provides additional evidence for this connection. Note also the association of both the Gandharvas and the Apsaras with humid, marshy landscapes and rivers; this, again, emphasizes the above-mentioned feature, given the regular association between water and liquid on the one hand ${ }^{60}$ and sexual activity on the other hand. In this sense, the (early Vedic) Apsaras are a perfect match for the plethora of seductive water nymphs

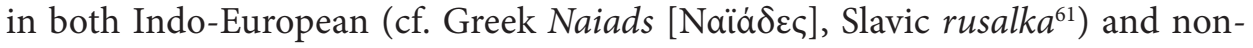
Indo-European mythologies; cf. the famous legend about Heracles' companion

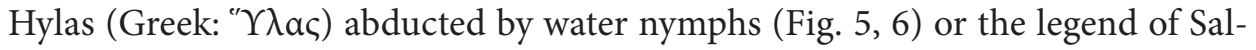
macis [ $\Sigma \alpha \lambda \mu \alpha \kappa i c]$, who attempted to rape Hermaphroditus (Fig. 7).

As regards the Centaurs, we find numerous episodes in Greek mythology that point to their hypersexuality. It should suffice to mention the story of their attempt to abduct Hippodamia and other Lapith women (Fig. 9) ${ }^{62}$.

\subsection{Hybrid or metamorphic (human/animal) nature}

While the dual nature of the Centaurs (combination of the half upper body of a human and the lower body and legs of a horse) does not require special comments $^{63}$, the hybrid character of the Gandharvas is, at first glance, less ob-

\footnotetext{
${ }^{59}$ As for the Gandharvas, see the brief discussion in Section 4 above.

${ }^{60}$ See also L.D. BARnett, Yama..., p. 706.

${ }^{61}$ Rus. pусалка, Pol. rusałka etc.

${ }^{62}$ See also P. DuBois, On Horse/Men, Amazons, and Endogamy, Aret 1979, 12, p. 37sqq.; W.F. HANSEN, Handbook of Classical Mythology, Santa Barbara 2004, p. 287, just to name a few relevant works. ${ }^{63}$ See also P. Kretschmer, Mythische..., p. 57; J.N. Bremmer, Greek Demons of the Wilderness: the Case of the Centaurs, [in:] Wilderness in Mythology and Religion. Approaching Religious Spatialities, Cosmologies, and Ideas of Wild Nature, ed. L. FeldT, Berlin 2012, p. 25-53.
} 
vious. Nevertheless, there are many features that point to the similar character of this figure.

First, the remarkable ability of the Gandharvas to appear in different shapes (shapeshifting) - as described in AVŚ 4, $37=$ AVP 12, 7-8 and discussed above (once as will-o'-the-wisps, once as a dog, once as an ape, once as a handsome young man) - clearly points to their metamorphic nature, which can be directly compared to the hybrid nature of the Centaurs. Second, we also find metamorphic features in some other figures of the Vedic pantheon related to the Gandharvas. Thus, Sarany $\bar{u}$ - the mother of Yama and Yamī according to their canonical genealogy - is said to have turned into a mare to run away from her husband, Vivasvant ${ }^{64}$. Third, the Iranian sea monster Gandarəba, albeit only poorly characterized in Iranian mythology, again points to the metamorphic character of the corresponding Proto-Indo-Iranian creature. Finally, the Old Iranian form gandarzba- has survived in several modern Iranian (in particular, Pamir) languages, where its reflexes refer to various monsters and shapeshifters, cf. Shughni žindūrv (< ${ }^{*}$ gandarba-) 'werewolf', žindìrv (< 'gandarbi-) 'she-werewolf'.

\section{3. (Semi-)equinal nature}

One of the main shapes regularly associated with the Gandharvas/Centaurs is that of the horse, which points to their [semi-]equinal nature. This feature is obvious for the Centaurs, but also not inexistent for the Gandharvas. As already mentioned in the preceding section, Saranyū, who is the mother of Yama and Yamī, is said to have turned into a mare to run away from her husband ${ }^{65}$. Moreover, clearly prone to beget twins, she was the mother of yet another twin pair, namely the dual gods Aśvins (note the etymology of their name: 'related to/having horses'). Although the anthropomorphic image of the Aśvins clearly prevails in the Vedic tradition, in later Hinduism they are often represented with the upper body of a horse and the lower body of a human, thus appearing as a mirror image of the Centaurs. Episodes in which some manipulations involve a horse head, mentioned in the context of the Aśvins (in RV 10, 116, 12 and Śatapatha-Brāhmaṇa 14, 1, 1, 18-24) might be regarded as indirect evidence for the more archaic character of their theriomorphism.

\footnotetext{
${ }^{64}$ On this legend, see in particular W. Doniger O'Flaherty, Sacred Cows and Profane Mares in Indian Mythology, HR 19, 1979, p. 5sqq.; P. JACKson, The Transformations of Helen. IndoEuropean Myth and the Roots of the Trojan Cycle, Dettelbach 2006 [= MSS, 23], p. 80-83. Note also the etymology of Saranyū, derived from the root sr 'run, speed' (often said of water); see M. MAYrhofer, EWAia, vol. II, p. 706-707 and P. JACKsON, The Transformations... This may be yet another indication, though indirect, of a connection between the Gandharvas and water.

${ }^{65}$ See W. Doniger O’Flaherty, Sacred Cows...; P. Jackson, The Transformations...
} 
It is interesting to note that in the Purānas and Epics (Harivamína), we find the legend of yet another demon, Keśin (Keśî), who takes the form of a huge horse, killed by Kṛșna (Fig. 10).

Although we only find this legend in post-Vedic texts, the origins of this demon can probably be traced as far back as the Atharvaveda. In an AVic spell against demons harmful for a pregnant woman, we find a reference to the demon Keśi (to compare with sarvakeśaká- in AVŚ 4, 37, $11 \approx$ AVP 12, 8, 6 quoted above?), which is said to cause harm to the foetus in the area of the female genitals:

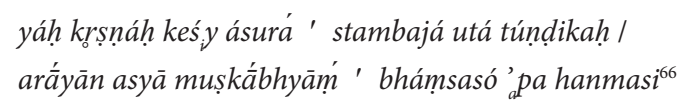

Who is the black asura Keśin [or: hairy], tuft-born and snout-mouthed, we beat away niggards from her genitals (vulvar lips), from her buttocks.

\subsection{Water/liquid $\sim$ hypersexuality $\sim$ horse: a cross-cultural correlation}

Furthermore, all of the aspects briefly discussed above - hypersexuality, equinal nature and aquatic character - are frequently related to each other in many world mythologies. Thus, universal correlations of the type Horse $\sim$ Water; Water/Liquid $\sim$ Sexuality; Horse $\sim$ Sexuality are very common ${ }^{67}$. The universal - or at least exceedingly common - connection between all these features cannot of course serve as evidence for the reconstruction of the corresponding mythologeme (Gandharva/Centaur) for Proto-Indo-European mythology, or even its Graeco-Aryan variety. However, these correlations testify to the general credibility of the connections between Gandharvas and Centaurs from a universal/typological point of view and, eventually, point to the likelihood of their genetic relationships. These two creatures, however different they might appear, undoubtedly occupy the same (or at least notably similar) niche within the two genetically related (Greek and Indo-Iranian) mythological pantheons. Accordingly, the negative conclusion formulated by Martin L. West ${ }^{68}$, who claims that the Gandharvas and the Centaurs "have virtually nothing in common mythologically", should be discarded as unjustified.

\footnotetext{
${ }^{66} \mathrm{AVŚ}, 8,6,5$.

${ }^{67}$ See e.g. W. Doniger O'Flaherty, Women, Androgynes, and Other Mythical Beasts, Chicago 1980; EAdem, On Hinduism, Oxford 2014, p. 459sq.; M. Odent, Water and Sexuality, London 1990; B.S. Thornton, Eros. The Myth of Ancient Greek Sexuality, Boulder 1998, p. 38-40; J.S. Lidke, A Union of Fire and Water: Sexuality and Spirituality in Hinduism, [in:] Sexuality and the World's Religions, ed. D.W. MaсhaceK, M.M. Wilcox, Santa Barbara 2003, p. 104sqq.; L. Graysmith, Sex and Gender in the Equine in Literature (unpublished MA thesis, Iowa State University, 2008).

${ }^{68}$ M.L. WeSt, Indo-European Poetry and Myth, Oxford 2007, p. 285.
} 


\section{Remarks on the possible origins of the Gandharvas/Centaurs}

The further origin of the Gandharvas/Centaurs remains obscure. While in the case of Indo-Iranian we can only rely on the linguistic and etymological speculations about possible non-Indo-European languages and cultures from which the Gandharvas could have been borrowed by the Indo-Iranians, in the case of the Greek Centaurs we also have some limited evidence from the history of the early contacts of ancient Greeks with other cultures. Possible sources of the Centaurs can be found in Near Eastern mythologies, particularly in Kassite mythology ${ }^{69}$.

Our knowledge of the Kassites, who ruled Babylonia at the end of the II millennium BC, is quite scarce. The non-Indo-European character of their language is beyond any doubt, but its possible genetic relations are obscure; there are some reasons to assume a connection with the Hurro-Urartian languages ${ }^{70}$ and thus, eventually, with the North Caucasian macrofamily. The lexical material of Kassite is only poorly known from a Kassite-Babylonian dictionary as well as some personal names and terms attested in Akkadian texts ${ }^{71}$, but we find some forms that might at least be relevant for the discussion of the hypothetical sources of

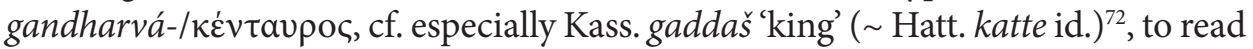
gandaš, where the stem is possibly $g^{y} a n^{d} z_{-}{ }^{73}$ and gidar (the name of a war god?) ${ }^{74}$.

The abundance of hybrid half-animal creatures in Kassite mythology has been repeatedly noticed in the literature ${ }^{75}$. The same feature characterizes the geographically and chronologically adjacent mythology of the Middle Assyrian Empire ${ }^{76}$. The assumption of the contacts between Kassites and Indo-Iranians is corroborated by the numerous Kassite names borrowed from Indo-Iranian (or Indo-Aryan).

\footnotetext{
${ }^{69}$ See especially E.A. Lawrence, The Centaur. Its History and Meaning in Human Culture, JPC 27, 1994, p. 57; V. Masciadri, Das Problem der Kentauren - die Griechen und das Wunderbare, [in:] Spinnenfuss und Krötenbauch: Genese und Symbolik von Kompositwesen, ed. P. MicheL, Zürich 2013, p. 65-85; M. Maturo, "Uomini-cavallo": genesi, elaborazione e memoria iconografica della figura del centauro, alcuni esempi, Ac 2, 2014, p. 7-40; A. ScoBIE, The Origins of 'Centaurs', Fol 89, 1978 , p. 142sqq.

${ }^{70}$ See T. SCHNEIDER, Kassitisch und Hurro-Urartäisch: Ein Diskussionsbeitrag zu möglichen lexikalischen Isoglossen, AFor 30, 2003, p. 372-381.

${ }^{71}$ See esp. K. JARITZ, Die kassitischen Sprachreste, Anthr 52, 1957, p. 850-898.

${ }^{72}$ Notice the interesting split $g a(n) d$-/kat-, remarkably parallel to the difference between the initial

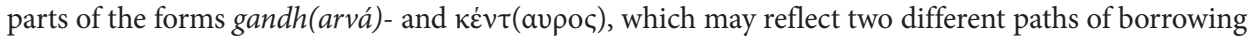

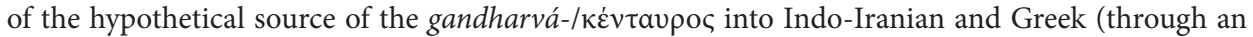
intermediary form of the Hatti type?), respectively.

${ }^{73}$ See T. Schneider, Kassitisch..., p. 324.

${ }^{74}$ See K. Jaritz, Die kassitischen..., p. 871sq.

${ }^{75}$ See, for instance, J. Black, A. Green, Gods, Demons and Symbols of Ancient Mesopotamia. An Illustrated Dictionary, London 1992, p. 63 and passim; I.M. SHEAR, Mycenaean Centaurs at Ugarit, JHS 122, 2002, p. 151, an. 38; A. TAHERI, The "Man-Bull" and the "Master of Animals» in Mesopotamia and in Iran, IJHIRI 20, 2013, p. 13-28.

${ }^{76}$ See, e.g. J. Black, A. Green, Gods...
} 
Although direct evidence for similar contacts between Kassites and Greeks has not (yet) been found, the possibility of the Centaurs having been borrowed by the Greeks from the Kassites (and/or some of their neighbours?), most probably through North-Western Anatolia, does not seem unlikely and has been suggested by several scholars ${ }^{77}$, cf. Fig. 11-12. Furthermore, the geographic location of the Kassites - approximately half-way between the home of the Greeks and the hypothetic homeland of the Indo-Iranians, to the north of the territory of the BMAC

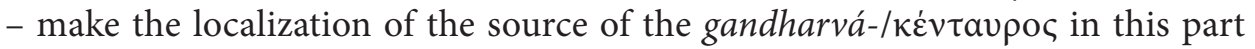
of the ancient world quite plausible.

\section{Yamī (vs. Yama): her semi-divine origin and half-human nature}

Let us return to the discussion of the mythological status of Yamī and her nature. Her origin from semi-divine (or even demonic) creatures, a Gandharva and an Apsara, notorious for hypersexuality, perfectly accounts for Yamı̄s hypersexuality and sexually explicit behaviour, radically differing from that of her brother Yama. As I mentioned above, Yamī can be described as a worthy heir of her parents - especially, of the lustful Gandharva. Most importantly, Yamī and Yama represent two diametrically opposite lines of behaviour and, eventually, two distinct ethic codices of conduct - at least as far as sexual relationships are concerned. Obviously, for Yamī incestual relationships with her brother are not impossible, whilst for Yama such sort of relation is a strict taboo ${ }^{78}$. Refusing to perform sex with her sister, Yama provides an important explanation for his reluctance to engage in such incestual relations. In RV 10, 10, 10, which is Yama's response to yet another of Yamī's invitations to start sexual relations, we read:

\section{à ghā tấ gachān úttarā yugắni 'yátra jāmáyạ̣ kṛnávann ájāmi ${ }^{79}$}

As I argue elsewhere ${ }^{80}$, the particle gha should be understood here as a consecutive connector, meaning 'then, in that case', and the passage in question can be rendered as follows:

[Yama:] [If we do it now], then / in that case, later generations will come, where kin will do [what is] im[proper for] kin.

Evidently, Yamī is warned by her brother about their incestual relationship's direct consequences for the future generations of humankind. It seems that Yama's

\footnotetext{
${ }^{77}$ See, e.g. E.A. LaWrence, The Centaur...; M. Maturo, "Uomini-cavallo"...; I.M. Shear, Mycenaean...

${ }^{78}$ Cf. Yama’s explicit refusal to have sex with Yamī in RV, 10, 10, 2a ná te sákhā sakhyám vașty etát

- Your friend [= Yama] does not want this [type of] partnership.

${ }^{79} \mathrm{RV}, 10,10,10 \mathrm{ab}$.

${ }^{80}$ L. Kulikov, The Vedic particle ghă reconsidered... (forthcoming).
} 
central message here is: not only is sexual relationship with a sister a strict taboo, but, moreover, performing sex would imply licensing this conduct as a norm for future human generations. In other words, Yama believes that what Yamī considers possible for them, as not (yet) humans, is inappropriate for them as humans. Yamî's hypersexuality, probably inherited from her non-human or semi-divine (demonic) parents - a Gandharva and an Apsara - is strictly rejected by Yama as incompatible with human ethics and moral norms.

We do not know how this clear-cut difference between the twins could have arisen, eventually resulting in their different status within the early Vedic mythological system. Yama becomes the first mortal doomed to die (as we know from the famous legend told in the Yajurveda), whilst Yamī inherits and at least partly preserves her non-human, semi-divine nature; accordingly, she retains divine immortality. Perhaps the key to this metamorphosis is Yama's journey over the sea mentioned in RV 10, 10, 1b (tiráh [...] cid arnavám jaganvắn '...even though he [= Yama] has gone across [...] the flood'). As Ulrich Schneider ${ }^{81}$ suggested in his analysis of the hymn, crossing a sea could be the reason for losing immortality and becoming a martya (mortal $)^{82}$. Whatever the exact origin of this feature, one might assume that the loss of immortality could have caused the complete 'humanification' of Yama, who thus became the first human, unlike Yamī. Let us remember that in RV 10, 10, 3b Yamī calls her brother éka- mártya- 'the only mortal'.

\section{Concluding remarks}

The further development of the relation between Yama and Yamī is, again, one of the obscure issues of Vedic mythology. After the famous Yajurvedic legend of Yama's death and creation of night, Yami virtually disappears in the shadow of Yama (who, as the first mortal, becomes the king of the dead) and vanishes from the Vedic mythological scenery altogether ${ }^{83}$. Classical Hinduism ascribes the merit of continuing the human race to Manu, yet another child of Vivasvant (and thus yet another (half-)brother of Yama and Yamī) - born not by Saranyū, but by her substitute, Savarna ${ }^{-84}$. Yamī is virtually unknown in the later, post-Vedic, literature, being partly replaced by Yamunā, and we do not know if she finally managed to seduce Yama and to beget offspring with him.

\footnotetext{
${ }^{81}$ U. SchneIder, Yama und Yamī..., p. 16sq.

${ }^{82}$ Note also that, as we know from classical Hinduism, crossing a sea should be avoided by the Brahmanas.

${ }^{83}$ As C. Malamoud, Yama, Yamī et les diverses manières de former une paire, [in:] Yama/Yima. Variations..., p. 107, notices, [1] e destin de Yamī [...] n'est autre que sa quasi disparition.

${ }^{84}$ Cf. RV, 10, 17, 2; see, for instance, A. Kunn, Saranyûu - 'Epıvvv́c, ZVS 1.5, 1852, p. 439-470; A.A. Macdonell, Vedic..., p. 139; see also M. Bloomfield, Contributions to the Interpretation of the Veda, JAOS 15, 1893, p. 172sqq.
} 
Evidence from Iranian mythology is of special interest. Although exact parallels to the explicit discussion of the brother-sister incest found in RV 10, 10 are lacking in Old Iranian (Avestan) and Middle Iranian texts, a similar myth existed in Iranian tradition. The motive of the incest (marriage) of Jam(šid), the Middle Iranian equivalent of Ved. Yama / Av. Yima, with his twin sister, Yimeh/Yimak, is well-known in Middle Iranian (Pāhlavī) tradition ${ }^{85}$. Some attempts have even been made to trace the Iranian incestual myth as far as the Avesta ${ }^{86}$, but the corresponding Avestan passage ${ }^{87}$ is too obscure to be used as conclusive evidence for this assumption. In any case, the myth of the incest of twins giving rise to humankind can safely be reconstructed for Proto-Indo-Iranian. Its Indic version, which does not contain any explicit mention of the committed incest (of which clear traces can be found in Iranian), may result from later editing and revision of a more complete proto-version ${ }^{88}$.

Further comparative studies of the Anatolian, Near Eastern and Central Asian mythologies, as well as the linguistic analysis of the material available from the languages used by the corresponding cultures, may shed more light on the origin and deeper genesis of this episode within Indo-Iranian and Indo-European mythology, thus clarifying both the origin of the primordial twins and the character of the relationships between them.

\section{Bibliography}

\section{Primary Sources}

Atharva-Veda Samhitā, trans. et comm. W.D. Whitney, ed. C.R. LAnman, vol. I-II, Cambridge Massachusetts 1905 [= Harvard Oriental Series, 7-8].

Atharvaveda (Šaunaka), trans. et comm. T. Ja. Elizarenkova, vol. I-III, Moskva 2005-2010.

Avesta. Die heiligen Bücher der Parsen, übersetzt auf der Grundlage von Chr. Bartholomae's altiranischem Wörterbuch, trans. F. WolfF, Strasbourg 1910.

\footnotetext{
${ }^{85}$ See, for instance, A.J. Carnoy, Iranian, [in:] The Mythology of All Races, vol. VI, Indian. Iranian, ed. L.H. Gray, G.F. Moore, Boston 1917, p. 310-311; C.R. Coulter, P. Turner, Encyclopedia of Ancient Deities, London 2000, p. 248, 517. The Middle Persian text Bundahišn preserves another version of the legend, where both Jam and his sister are said to copulate with demons (thus used as substitutes for the sister/brother in sexual relations), to produce a variety of creatures such as monkeys, bears etc. This probably points to a secondary revision of the original incestual myth.

${ }^{86}$ See W. Lentz, Yima and Khwarenah in the Avestan Gathas, [in:] A Locust's Leg. Studies in Honour of S.H. Taqizadeh, ed. W.B. Henning, E. Yarshater, London 1962, p. 131-134 and J. Kellens, Yima, magicien entre les dieux et les hommes, [in:] Orientalia J. Duchesne-Guillemin Oblata, Leuven-Leiden 1984 [= AIr, 23], p. 267-281 for discussion.

${ }^{87}$ Yasna 30, 3 (see, e.g., P.O. SkJÆRvø, The Spirit of Zoroastrianism, New Haven-London 2011, p. 45).

${ }^{88}$ See, for instance, B. SikLós, The Evolution of the Buddhist Yama, [in:] The Buddhist Forum, vol. IV, ed. T. SKORUPSKI, London 1996, p. 168.
} 
Hymnes spéculatifs du Véda, trans. et comm. L. Renou, Paris 1956.

Rigveda. Mandaly IX-X, trans. et comm. T.Ja. Elizarenkova, Moskva 1999.

The Rigveda. The Earliest Religious Poetry of India, vol. I-III, trans. et comm. S.W. JAMIson, J.P. BRERETON, New York 2014.

Der Rigveda oder die heiligen hymnen der Brâhmana, vol. I-II, trans. A. Ludwig, Prag 1876.

Der Rigveda oder die heiligen hymnen der Brâhmana, vol. IV-V, Commentar zur Rigveda-übersetzung A. Ludwig, Prag-Leipzig 1883.

The Rig Veda. An Anthology. One Hundred and Eight Hymns, trans. et comm. W. Doniger O'FlaHERTY, London 1981.

Der Rig-Veda, vol. I-III, trans. et comm. K.F. Geldner, Cambridge Massachusetts 1951 [= Harvard Oriental Series, 33-35].

Rig-Veda, vol. I-II, trans. et comm. H. Grassmann, Leipzig 1876-1877.

\section{Secondary Literature}

Barnett L.D., Yama, Gandharva, and Glaucus, "Bulletin of the School of Oriental Studies" 4, 1928, p. 703-716.

Belardi W., Consonanze mediterranee e asiatiche con il nome dei Centauri, "Studi e materiali di storia delle religioni" 20, 1996, p. 23-53.

Black J., Green A., Gods, Demons and Symbols of Ancient Mesopotamia. An Illustrated Dictionary, London 1992.

Bloomfield M., Contributions to the Interpretation of the Veda, "Journal of the American Oriental Society" 15, 1893, p. 143-188.

Bodewitz H.W., The Dialogue of Yama and Yamī (RoV. 10, 10), "Indo-Iranian Journal" 52, 2009, p. $251-285$.

Böнtlingk O., Rотн R., Sanskrit-Wörterbuch, vol. I-VII, St. Petersburg 1855-1875.

Bremmer J.N., Greek Demons of the Wilderness: the Case of the Centaurs, [in:] Wilderness in Mythology and Religion. Approaching Religious Spatialities, Cosmologies, and Ideas of Wild Nature, ed. L. FELDT, Berlin 2012, p. 25-53.

Carnoy A.J., Iranian, [in:] The Mythology of All Races, vol. VI, Indian. Iranian, ed. L.H. Gray, G.F. Moore, Boston 1917, p. 251-351.

Chantraine P. et al., Dictionnaire étymologique de la langue grecque. Histoire des mots, Paris 1968.

Coomaraswamy A.K., Yakșas, pars 1-2, Washington 1928-1931.

Coulter C.R., Turner P., Encyclopedia of Ancient Deities, London 2000.

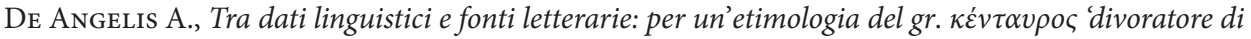
viscere, "Glotta" 85, 2009, p. 59-74.

Doniger O'Flaherty W., On Hinduism, Oxford 2014.

Doniger O'Flaherty W., Sacred Cows and Profane Mares in Indian Mythology, "History of Religions" 19, 1979, p. 1-26.

Doniger O'Flaherty W., Women, Androgynes, and Other Mythical Beasts, Chicago 1980.

DuBois P., On Horse/Men, Amazons, and Endogamy, "Arethusa" 1979, 12, p. 35-49.

Dumézil G., Le Problème des centaures. Étude de mythologie comparée indo-européenne, Paris 1929.

Ehni J., Der Vedische Mythus des Yama verglichen mit den analogen Typen der Persischen, Griechischen und Germanischen Mythologie, Strassburg 1890. 
FrISK H., Griechisches etymologisches Wörterbuch, Heidelberg 1960.

Graysmith L., Sex and Gender in the Equine in Literature (unpublished MA thesis, Iowa State University, 2008).

HaAs C., Wie man den Veda lesen kann. Gandharva und die "Zwischenzustände" im Rgveda und im Kommentar des Sāyana. Wege der Interpretation eines archaischen Textes, Göttingen 2004 [= Historische Sprachforschung, 43].

HANSEN W.F., Handbook of Classical Mythology, Santa Barbara 2004.

Ivanov V.V., Toporov V.N., K probleme lmš. jumis i baltijskogo bliznečnogo kul'ta, “Балто-славянские исследования" / "Balto-slavjanskie issledovanija" 1981, p. 140-175.

JACKson P., The Transformations of Helen. Indo-European Myth and the Roots of the Trojan Cycle, Dettelbach 2006 [= Münchener Studien zur Sprachwissenschaft, 23].

Jamison S.W., [rec.:] C. Haas, Wie man den Veda lesen kann... - "Journal of the American Oriental Society" 128, 2008, p. 394-395.

JARITZ K., Die kassitischen Sprachreste, “Anthropos” 52, 1957, p. 850-898.

Jespersen O., A Modern English Grammar on Historical Principles, pars 2, Syntax, vol. I, LondonCopenhagen 1949.

JEŽIĆ M., Rgvedski himni. Izvori indijske kulture i indoeuropsko nasljeđe, Zagreb 1987.

Kellens J., Yima, magicien entre les dieux et les hommes, [in:] Orientalia J. Duchesne-Guillemin Oblata, Leuven-Leiden 1984 [= Acta Iranica, 23], p. 267-281.

Kretschmer P., Mythische Namen. 9. Die Kentauren, "Glotta" 10, 1920, p. 50-58.

Kunn A., Gandharven und Kentauren, "Zeitschrift für Vergleichende Sprachforschung” 1.6, 1852, p. 513-542.

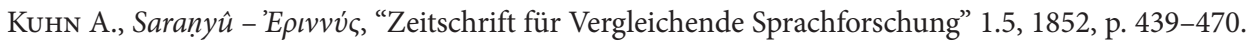

Kulıkov L., Vedic āhanás- and Its Relatives/Cognates within and outside Indo-Iranian, [in:] Farnah. Indo-Iranian and Indo-European Studies in Honor of Sasha Lubotsky, Ann Arbor 2018, p. 153-161.

Kulikov L., The Vedic particle ghä reconsidered: Evidence from Vedic and beyond (forthcoming).

Kulikov L., The Vedic -ya-presents. Passives and Intransitivity in Old Indo-Aryan, Amsterdam 2012 [= Leiden Studies in Indo-European, 19].

Lanman C.R., A Statistical Account of Noun-inflection in the Veda, "Journal of the American Oriental Society" 10, 1880, p. 325-601.

Lawrence E.A., The Centaur. Its History and Meaning in Human Culture, "Journal of Popular Culture" 27, 1994, p. 57-68.

Lentz W., Yima and Khwarenah in the Avestan Gathas, [in:] A Locust's Leg. Studies in Honour of S.H. Taqizadeh, ed. W.B. Henning, E. Yarshater, London 1962, p. 131-134.

LidKe J.S., A Union of Fire and Water: Sexuality and Spirituality in Hinduism, [in:] Sexuality and the World's Religions, ed. D.W. MachaceK, M.M. Wilcox, Santa Barbara 2003.

LinColn B., The Lord of the Dead, "History of Religions" 20, 1981, p. 224-241.

Luвотsкy A., The Indo-Iranian Substratum, [in:] Early Contacts between Uralic and Indo-European. Linguistic and Archaeological Considerations, ed. C. Carpelan, A. Parpola, P. Koskikallio, Helsinki 2001 [= Mémoires de la Société Finno-ougrienne, 242], p. 301-317.

Lubotsкy A., RV. ávidhat, [in:] Früh-, Mittel-, Spätindogermanisch. Akten der IX. Fachtagung der Indogermanischen Gesellschaft vom 5. bis 9. Oktober 1992 in Zürich, ed. G. Dunkel et al., Wiesbaden 1994, p. 201-206. 
Macdonell A.A., Vedic mythology, Strassburg 1897.

Malamoud C., Yama, Yamī et les diverses manières de former une paire, [in:] Yama/Yima. Variations indo-iraniennes sur la geste mythique = Variations on the Indo-Iranian myth of Yamal Yima, ed. S. Azarnouche, C. Redard, Paris 2012 [= Publications de l'Institut de Civilisation Indienne. Série in $\left.8^{\circ}, 81\right]$, p. 95-110.

Masciadri V., Das Problem der Kentauren - die Griechen und das Wunderbare, [in:] Spinnenfuss und Krötenbauch: Genese und Symbolik von Kompositwesen, ed. P. Michel, Zürich 2013, p. 65-85.

Maturo M., "Uomini-cavallo": genesi, elaborazione e memoria iconografica della figura del centauro, alcuni esempi, "Acme" 2, 2014, p. 7-40.

MaYrhofer M., EWAia = Etymologisches Wörterbuch des Altindoarischen, vol. I-III, Heidelberg 1986-2001.

Mayrhofer M., Kurzgefaßtes etymologisches Wörterbuch des Altindischen = A Concise Etymological Sanskrit Dictionary, vol. I-IV, Heidelberg 1956-1980.

Meyer E.H., Indogermanische Mythen, vol. I, Gandharven-Kentauren, Berlin 1883.

NAPOL'CKICH V.V., Kentavr gandcharva drakon medved': k evoljucii odnogo mifologičeskogo obraza v Severnoj Evrazii, "Nartamongæ. The Journal of Alano-Ossetic Studies" 5, 2008, p. 43-63.

Norman Brown W., [rec.:] A.K. Coomaraswamy, Yaksas, pars 1-2, Washington 1928-1931, "Journal of the American Oriental Society" 51, 1931, p. 286-288.

Odent M., Water and Sexuality, London 1990.

Oettinger N., Before Noah: Possible Relics of the Flood-myth in Proto-Indo-Iranian and Earlier, [in:] Proceedings of the $24^{\text {th }}$ Annual UCLA Indo-European Conference, ed. S.W. JAMIson, H.C. Melchert, B. Vine, Bremen 2013, p. 169-183.

Oldenberg H., Rgveda. Textkritische und exegetische Noten, vol. II, Siebentes bis zehntes Buch, Berlin 1912.

Oldenberg H., Vedische Untersuchungen, "Zeitschrift der Deutschen Morgenländischen Gesellschaft" 63, 1909, p. 287-302.

Pinault G.-J., Further Links between the Indo-Iranian Substratum and the BMAC Language, [in:] Themes and Tasks in Old and Middle Indo-Aryan linguistics, ed. B. Tikкanen, H. Hettrich, Delhi 2006, p. 167-196.

Pinault G.-J., Sur l'hymne védique dialogué de Yama et Yamī (RV X.10), [in:] Yama/Yima. Variations indo-iraniennes sur la geste mythique = Variations on the Indo-Iranian myth of Yamal Yima, ed. S. Azarnouche, C. Redard, Paris 2012 [= Publications de l'Institut de Civilisation Indienne. Série in $8^{\circ}, 81$ ], p. 139-178.

Pischel R., Vedische Studien, vol. I, Stuttgart 1889.

Renou L., Études védiques et pānninéennes, vol. XVI, Paris 1967.

Schnaus S., Die Dialoglieder im altindischen Rigveda. Kommentar unter besonderer Berücksichtigung textlinguistischer Kriterien, Hamburg 2008.

SCHNeider T., Kassitisch und Hurro-Urartäisch: Ein Diskussionsbeitrag zu möglichen lexikalischen Isoglossen, "Altorientalische Forschungen" 30, 2003, p. 372-381.

Schneider U., Yama und Yamī (RoV X 10), "Indo-Iranian Journal" 10, 1967, p. 1-32.

Scobie A., The Origins of 'Centaurs', "Folklore" 89, 1978, p. 142-147.

Shear I.M., Mycenaean Centaurs at Ugarit, "Journal of Hellenic Studies" 122, 2002, p. 147-153.

SikLós B., The Evolution of the Buddhist Yama, [in:] The Buddhist Forum, vol. IV, ed. T. Sкorupsкi, London 1996, p. 165-189. 
SKJÆRvø P.O., The Spirit of Zoroastrianism, New Haven-London 2011.

TAHeri A., The "Man-Bull" and the "Master of Animals» in Mesopotamia and in Iran, "International Journal of Humanities of the Islamic Republic of Iran" 20, 2013, p. 13-28.

Thite U.G., Gandharvas and Apsarasas in the Veda, "Journal of the Indian Musicological Society" 18,1987 , p. 52-63.

Thornton B.S., Eros. The Myth of Ancient Greek Sexuality, Boulder 1998.

Uhlenbeck C.C., Kurzgefasstes etymologisches Wörterbuch der altindischen Sprache, Amsterdam $1898 / 1899$.

West M.L., Indo-European Poetry and Myth, Oxford 2007.

\begin{abstract}
This paper focuses on the mythology of Yamī and her twin-brother Yama (the first humans according to Indo-Iranian mythology), their non-human origin and some aspects of Yamî’s behaviour which presumably betray a number of features of a female half-deity.
\end{abstract}

The relationships between Yamī and Yama are the central topic of the dialogue hymn Rgveda 10.10, where Yamī attempts to seduce her twin to incest in order to produce offspring and thus continue the human race. This offer is refused by Yama, who refers to the inappropriateness of incest. Although Yamī and Yama are humans according to the Vedic tradition, their origin from two half-deities - a Gandharva father and an Apsara mother - remains inexplicable: how could a couple of non-human beings (half-deities or demons) give birth to humans? Obviously, the mythological status of the twins should be reconsidered. I argue that at least one of them, Yamī, retains immortality and some other features of the non-human (semi-divine) nature. On the basis of the analysis of the Yama and Yamī hymn and some related Vedic texts, I argue that this assumption may account for certain peculiarities of Yamîs behaviour - particularly her hypersexuality (which can be qualified as demonic type of behaviour), as opposed to the much more constrained, human type of conduct displayed by Yama. Given the notoriously lustful character of the Gandharvas, an origin from this semi-divine creature may account for Yamî̀s hypersexuality.

Although the word gandharvá- does not have Indo-European etymology, we can find possible Indo-European parallels. In particular, the Gandharvas are comparable with the Centaurs, which cannot be etymologically related but possibly originate in the same non-Indo-European source. There are some reasons to assume that both words are borrowed from the Kassite language and mythology, which, in turn, may have been related to the language and culture of the Proto-North-Caucasians.

Although we do not find exact equivalents of Yamī outside of the Indo-Iranian pantheon, indirect parallels can be found in other Indo-European traditions. The Apsaras (water nymphs) can be compared to a variety of water deities (nymphs) in Greek mythology, such as the Naiads, or to the Slavic rusalki.

Keywords: Yamī, Yama, Indo-Iranian mythology, Rgveda

Leonid Kulikov

Ghent University

Faculty of Arts and Philosophy

Department of Linguistics

Blandijnberg 2

B-9000 Ghent, Belgium

leonid.kulikov@ugent.be 


\section{ILLUSTRATIONS}

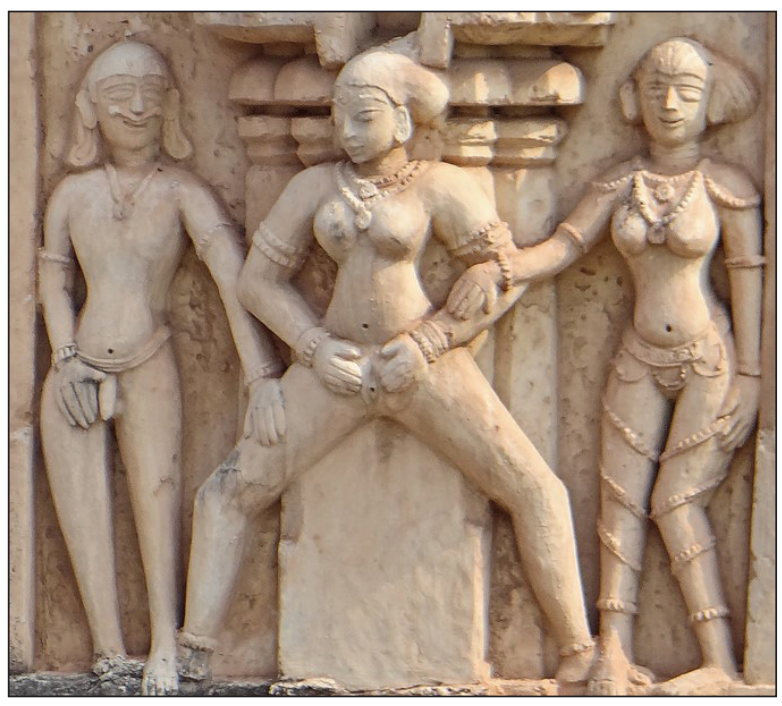

Fig. 1a. A Sculpture in Virupaksha Temple, Hampi, Karnataka, Southern India $\left(7^{\text {th }}\right.$ cent. AD)

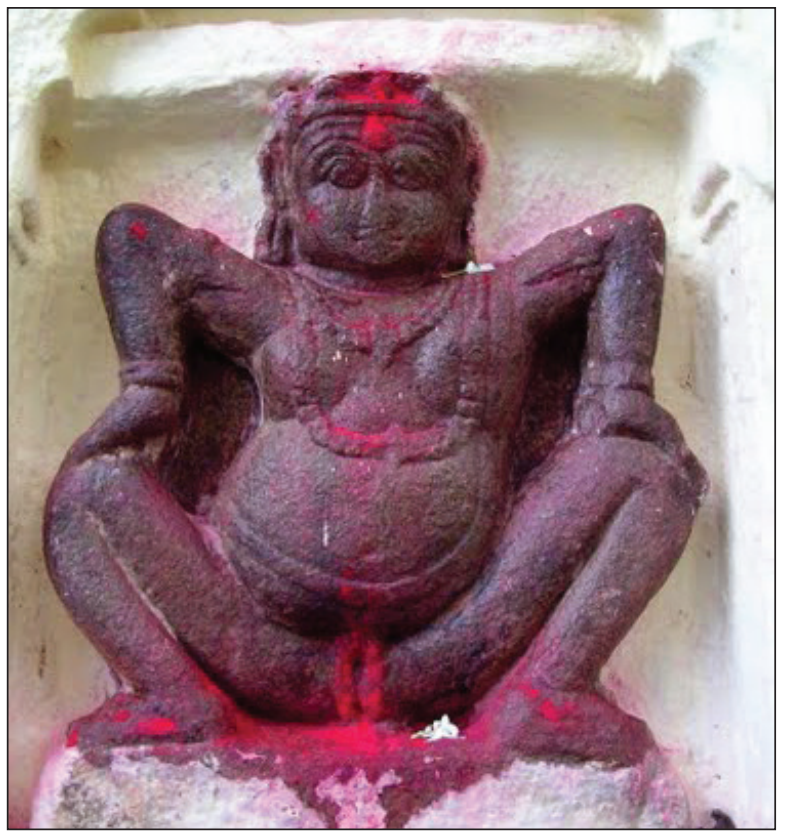

Fig. 1b. Kamakhya, Tantric goddess of desire, North-East India (Assam) 


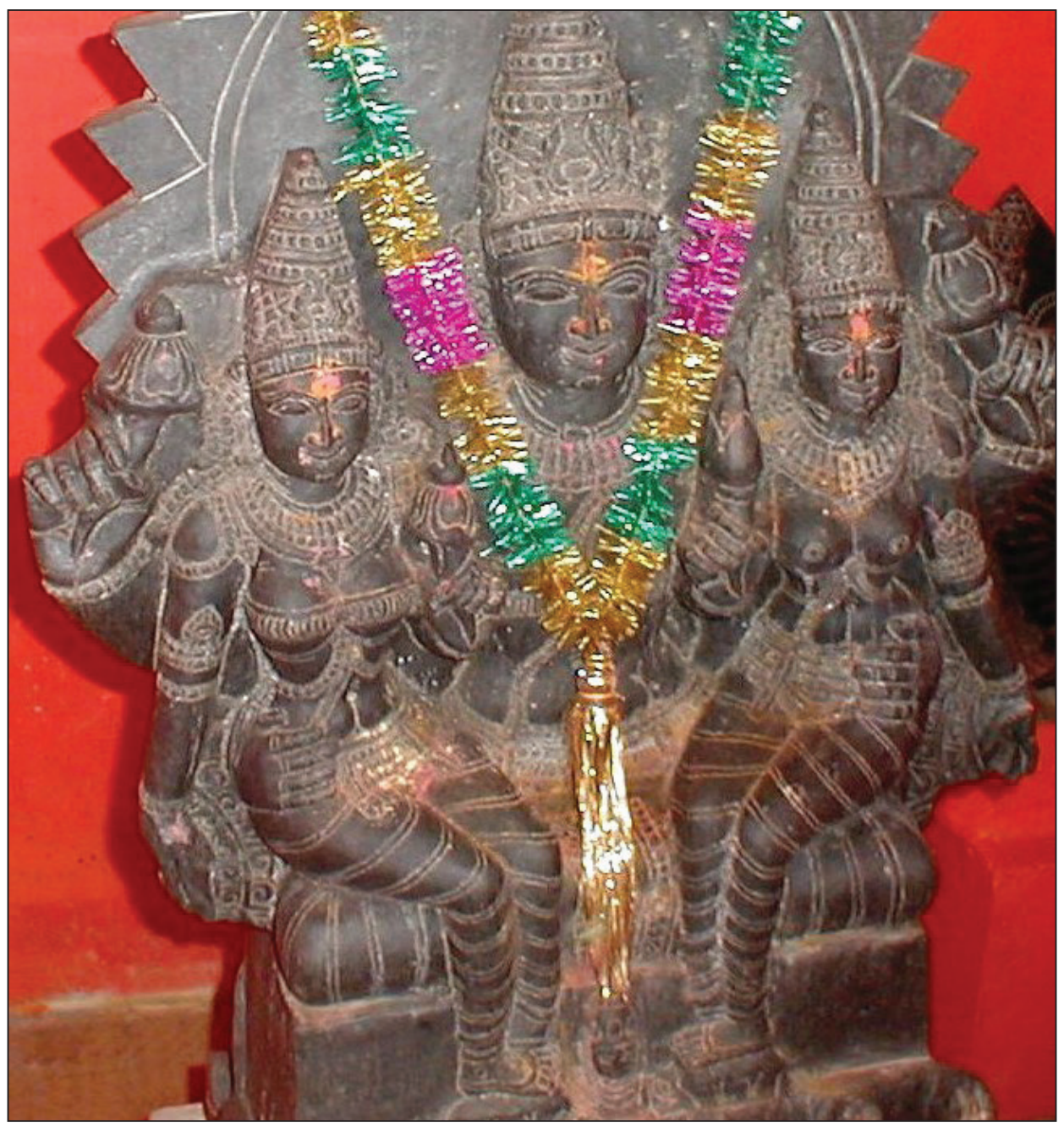

Fig. 2. Vivasvant-Sūrya with his consorts Saraṇyū and Chāyā, Surendrapuri Temple 


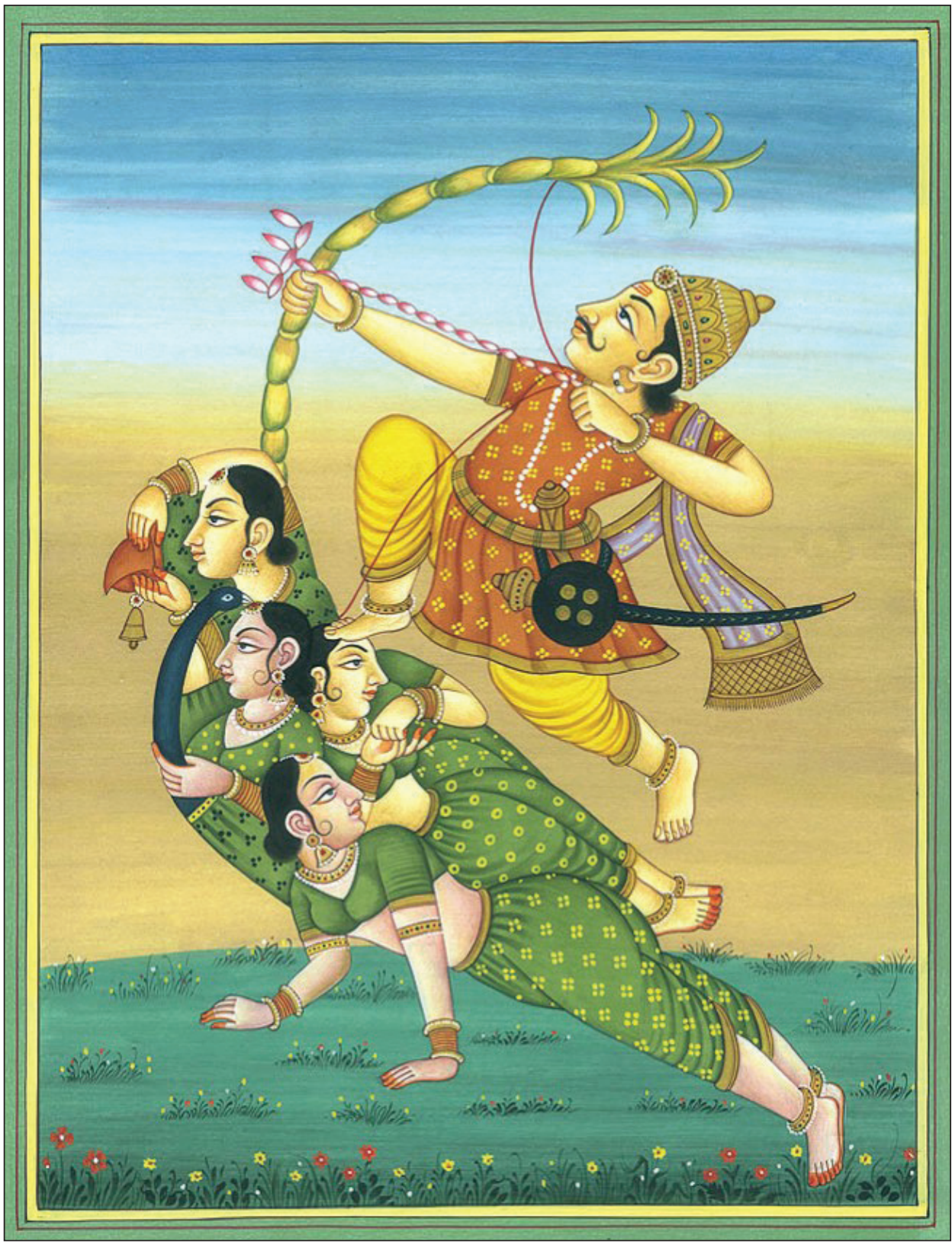

Fig. 3. Kandarpa, or Kāmadeva (love god) 


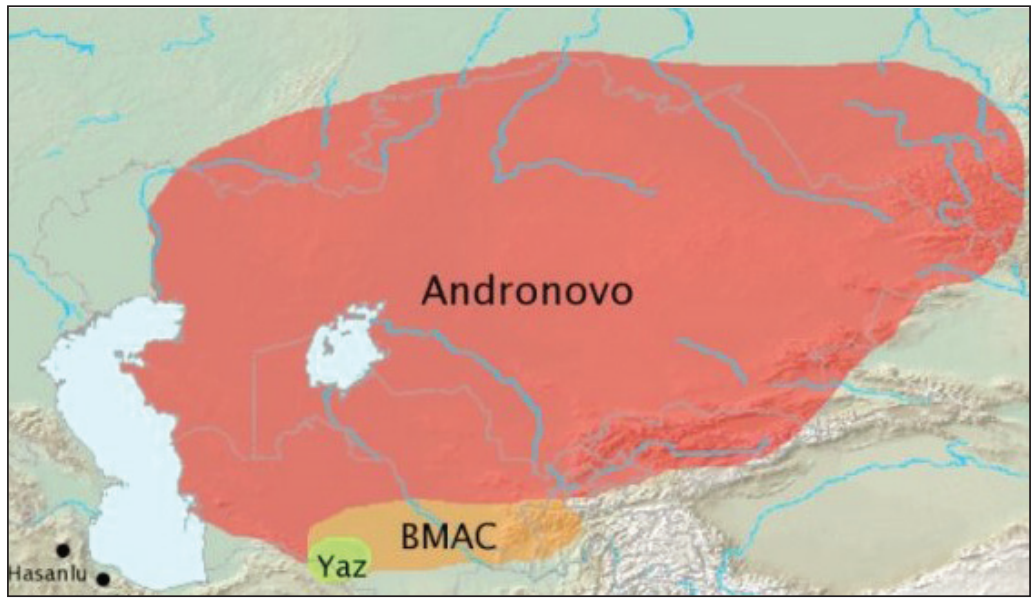

Fig. 4. Andronovo culture (Proto-Indo-Iranians?) and BMAC

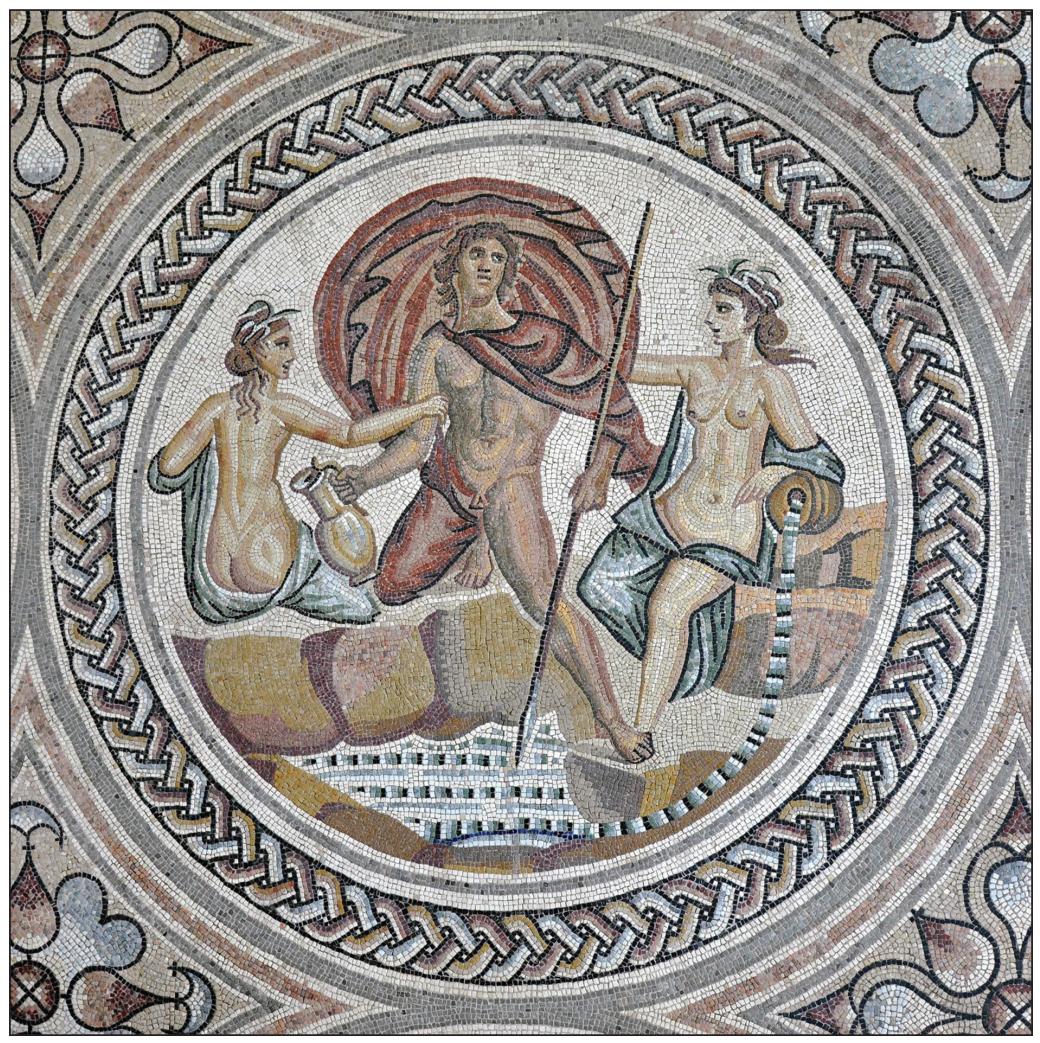

Fig. 5. Hylas and the Nymphs, a Gallo-Roman mosaic, $2^{\text {nd }}-3^{\text {rd }}$ century AD (Musée Gallo-Romain de Saint-Romain-en-Gal) 


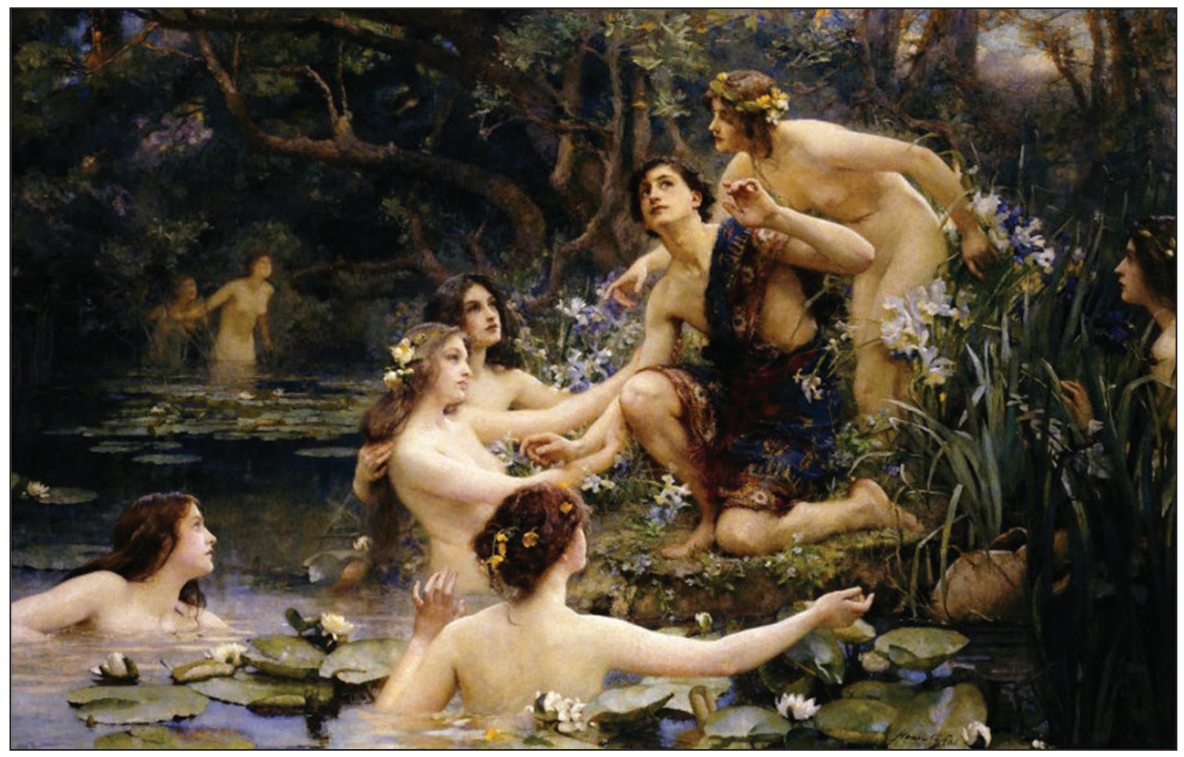

Fig. 6. Henrietta Rae, Hylas and the Water Nymphs, 1910

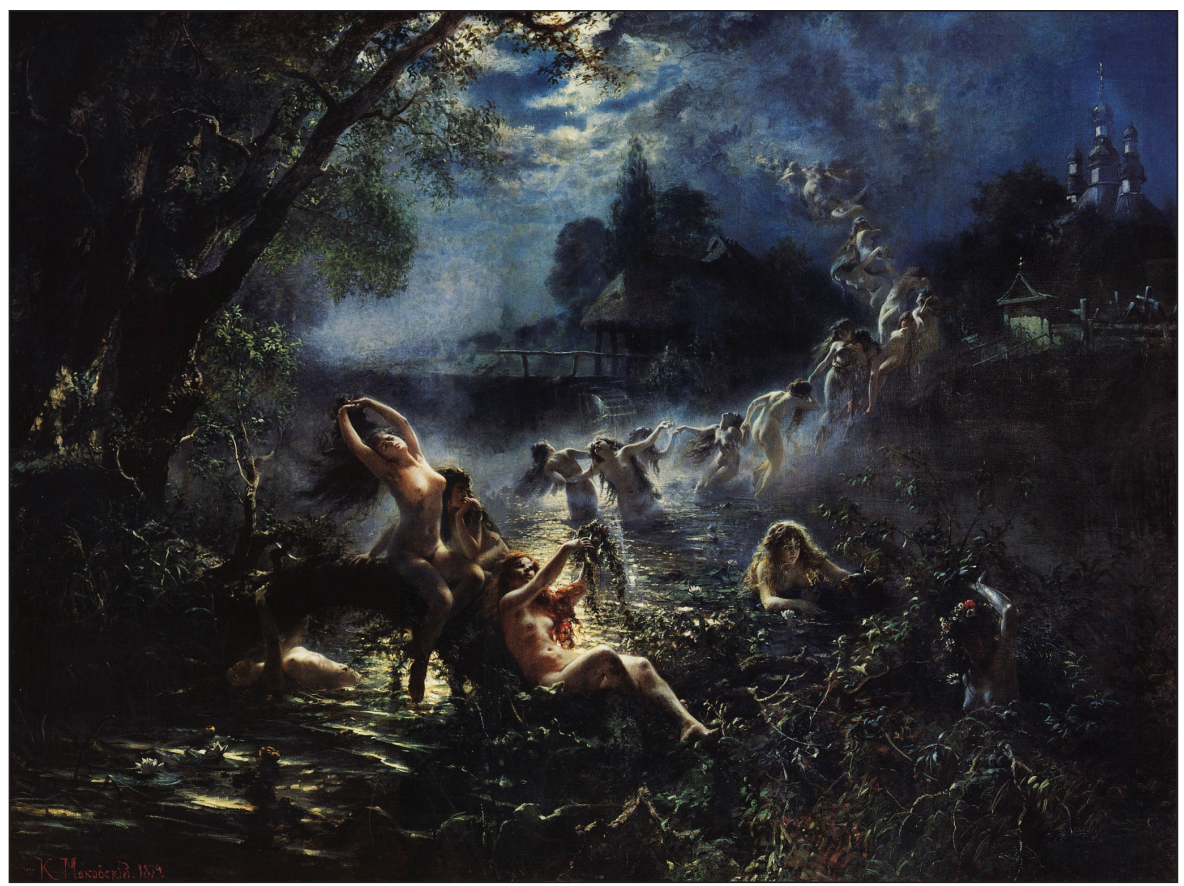

Fig. 7. К. MакоvsкiJ, Mermaids [К. Маковский, Русалки], 1879 (The State Russian Museum, Saint Petersburg) 


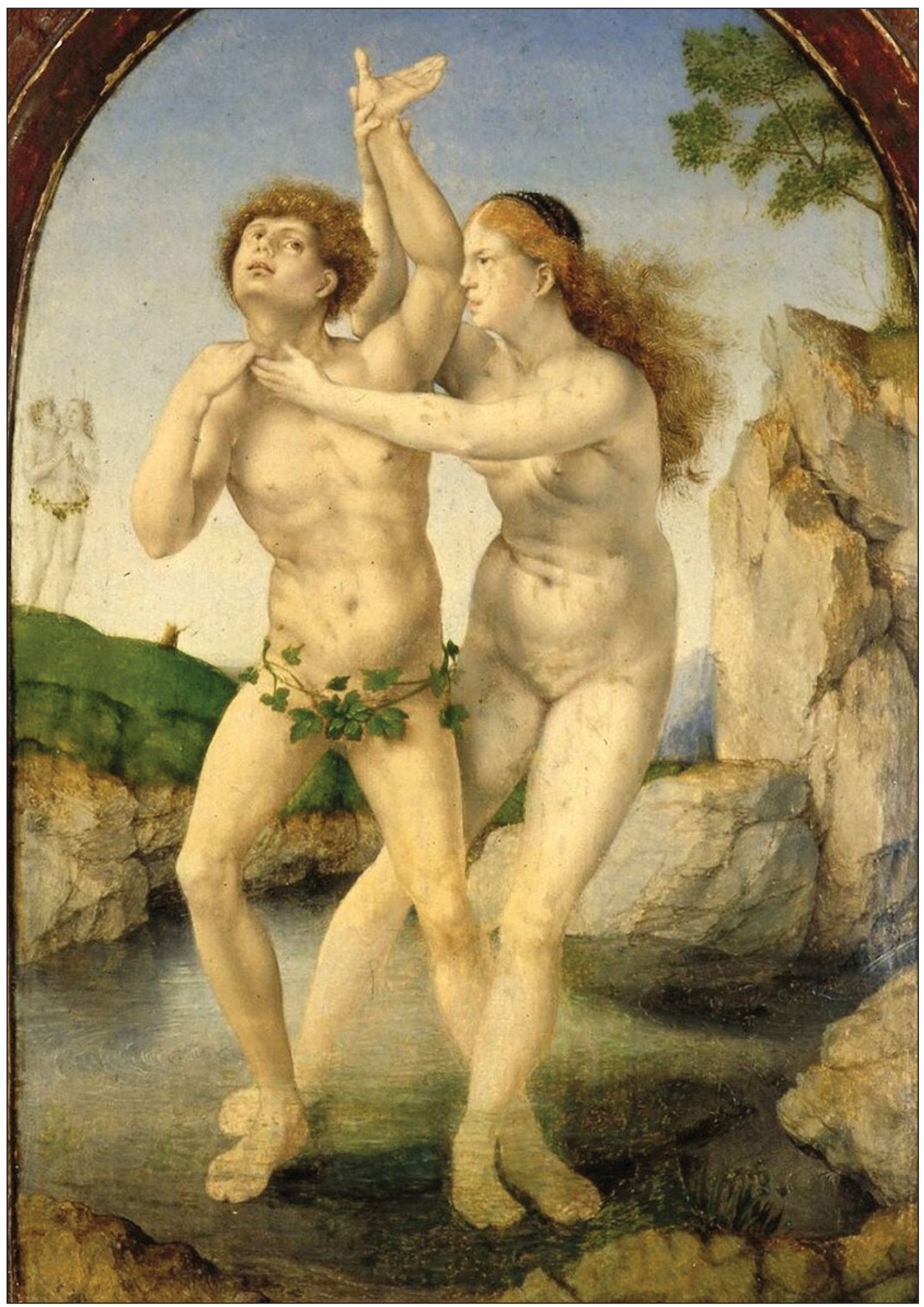

Fig. 8. Jan Gossaert, Salmacis, c. 1520 (Museum Boijmans Van Beuningen, Rotterdam) 


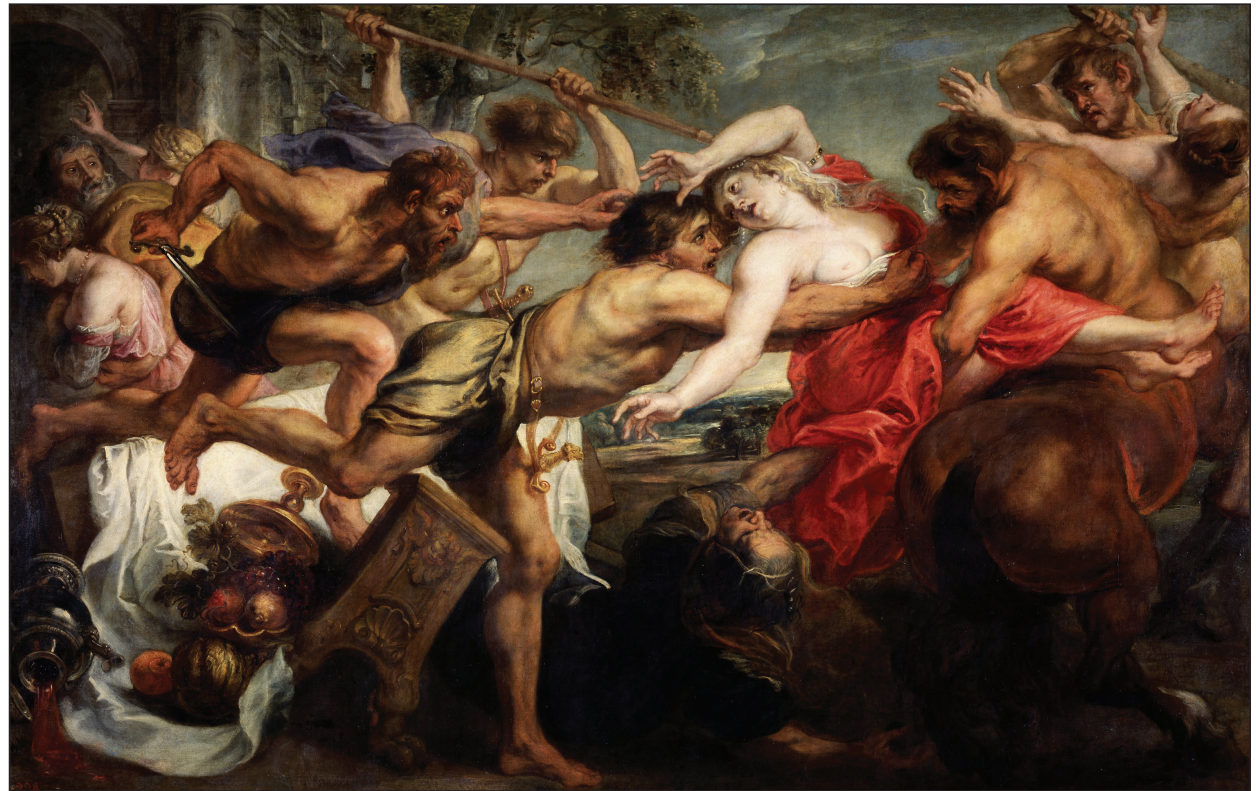

Fig. 9. Peter Paul Rubens, The Rape of Hippodame, 1636-1638 (Museo del Prado, Madrid)

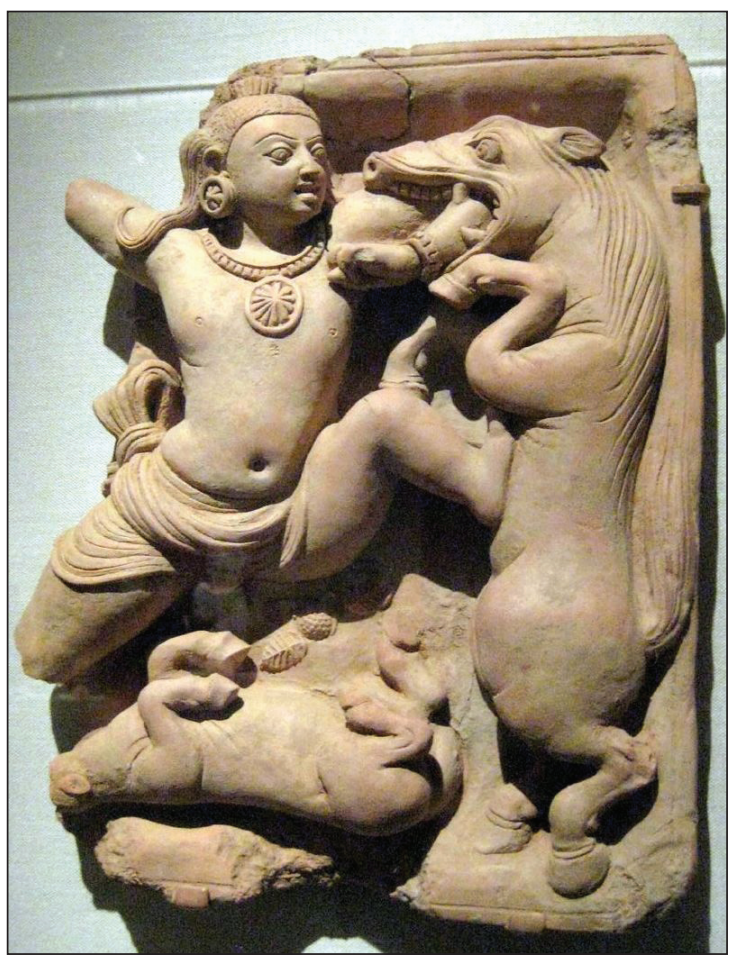

Fig. 10. Kṛṣna killing the horse demon Keśīi, Gupta sculpture, $5^{\text {th }}$ century $\mathrm{AD}$ 
Fig. 11-12. A winged horse-man Centaur on the side of the land grant to Hasardu kudurru (boundary stone), a four-sided limestone memorial stele, late $2^{\text {nd }}$ millennium BC (BM 90829)
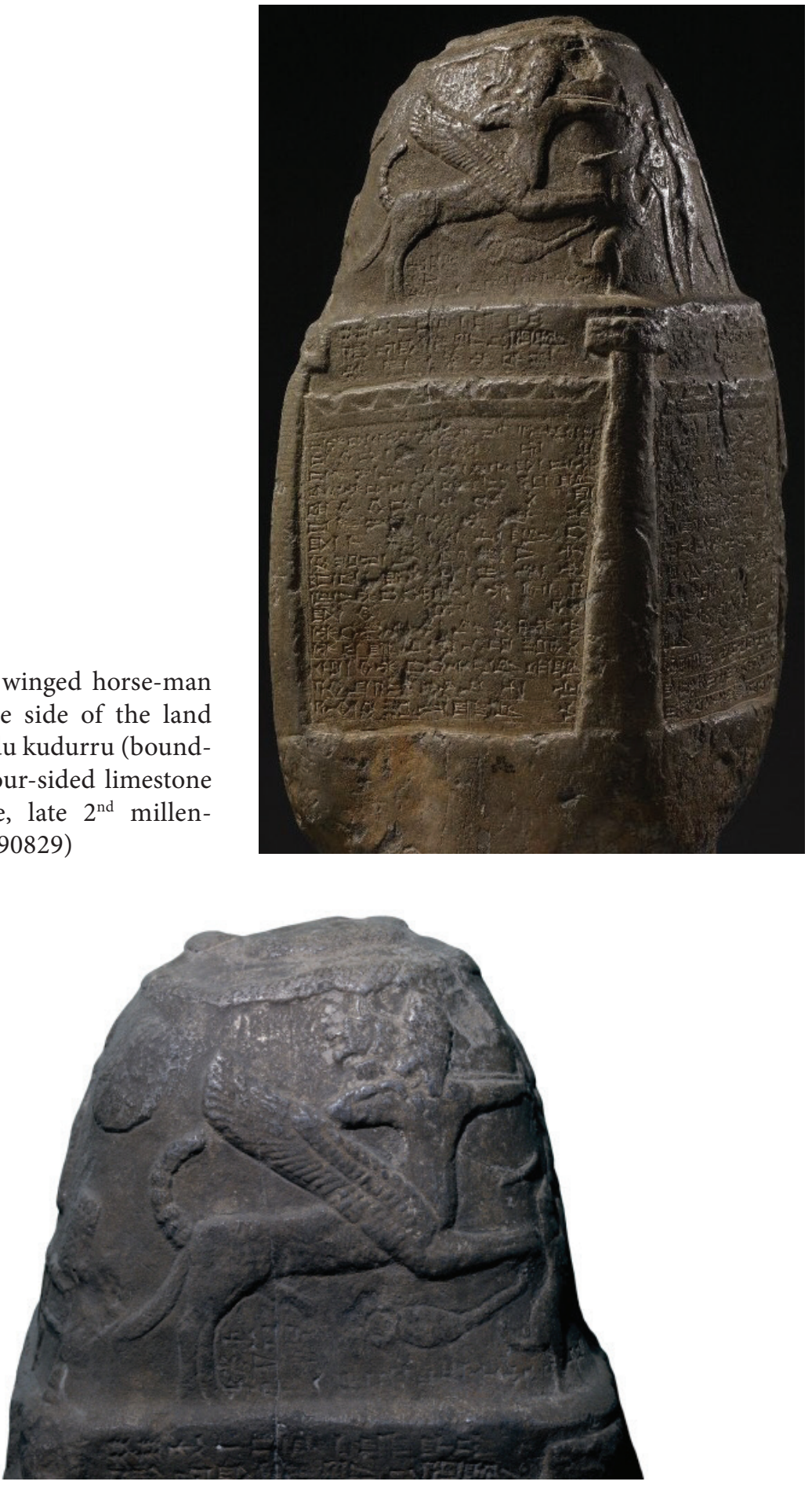